\title{
Dopamine-glutamate reciprocal modulation of release and motor responses in the rat caudate-putamen and nucleus accumbens of "intact" animals
}

Hélène N. Davida,b, Marc Ansseaua, Jacques H. Abrainib

aUnité de Psychologie Médicale, CHU Sart-Tilman, B 4000 Liège, Belgium

${ }^{b}$ Université de Caen - CNRS, UMR 6185, Centre CYCERON, Boulevard Henri Becquerel, 14074 Caen cedex, France

KEYWORDS: Striatum; Nucleus accumbens; D1-like receptor; D2-like receptor; Glutamatergic ionotropic receptor; Glutamatergic metabotropic receptor; functional interactions; Locomotor activity; Neurochemistry

\section{ABSTRACT}

Functional interactions between dopaminergic neurotransmission and glutamatergic neurotransmission are well known to play a crucial integrative role in the striatum, the major input structure of the basal ganglia now widely recognized to contribute to the control of motor activity and movements but also to the processing of cognitive and limbic functions. However, the nature of these interactions is still a matter of debate and controversy. This review (1) summarizes anatomical data on the distribution of dopaminergic and glutamatergic receptors in the striatum-accumbens complex, (2) focuses on the dopamine-glutamate interactions in the modulation of each other's release in the striatum-accumbens complex, and (3) examines the dopamine-glutamate interactions in the entire striatum involved in the control of locomotor activity. The effects of dopaminergic and glutamatergic receptor selective agonists and antagonists on dopamine and glutamate release as well on motor responses are analyzed in the entire striatum, by reviewing both in vitro and in vivo data. Regarding in vivo data, only findings from focal injections studies in the nucleus accumbens or the caudate-putamen of "intact" animals are reviewed. Altogether, the available data demonstrate that dopamine and glutamate do not uniformly interact to modulate each others' release and postsynaptic modulation of striatal output neurons. Depending on the receptor subtypes involved, interactions between dopaminergic and glutamatergic transmission vary as a multiple and complex combination of tonic, phasic, facilitatory, and inhibitory properties. 


\section{Introduction}

Dopamine-glutamate reciprocal modulations play a major integrative role in the striatum that is the major input structure of the basal ganglia now widely recognized to contribute not only to the control of motor activity and movements but also to the processing of cognitive and "limbic" (emotional and motivational) functions $[17,96,144]$. Because of this, dopamine-glutamate interactions have been extensively studied, leading to a matter of debate and controversy for nearly three decades. Despite the fact that synaptic contacts between dopaminergic fibers, arising from the substantia nigra and the ventral tegmental area, and glutamatergic axon terminals, arising from the whole cerebral cortex, the thalamus, and limbic structures, are rare in the striatum [21], evidence has been accumulated that dopamine and glutamate, released from non-junctional varicosities and/or spilled over from the synaptic cleft, can interact directly through activation of extra-synaptic receptors (the so-called volume neurotransmission) or indirectly through striatal interneurons in a complex manner both at the presynaptic and postsynaptic levels [64].

Reciprocal modulation between dopamine and glutamate in the striatum is further complicated by the heterogeneity of receptors and subtypes of receptors activated by these neurotransmitters. Glutamate acts on two types of glutamatergic receptors: the ionotropic glutamatergic (iGlu) receptors that are ion channel-coupled receptors and comprise the $\mathrm{N}$ methyl-d-aspartate (NMDA) receptors and the AMPA/kainate receptors (that include both the amino-3-hydroxy-5-methyl-4-isoxazoleproprionate (AMPA) receptors and the kainate receptors) [52]; and the metabotropic glutamatergic (mGlu) receptors that are G-proteinscoupled receptors and comprise three groups, namely the group I mGlu receptors (that includes the mGlu1 and mGlu5 receptors), the group II mGlu receptors (that includes the mGlu2 and mGlu3 receptors) and the group III mGlu receptors (that includes the mGlu4, mGlu6, mGlu7, and mGlu8 receptors) [160]. Dopamine acts on two classes of receptor subtypes that are coupled to G-proteins, namely the D1-like receptors (that include the D1 and D5 receptors) and the D2-like receptors (that include the D2, D3, D4 receptors) [186].

This review briefly summarizes anatomical data on the distribution of dopaminergic and glutamatergic receptors in the striatum complex (i.e., the caudate-putamen and the nucleus accumbens), and then focuses on particular and relevant aspects of dopamine-glutamate interactions, which are the reciprocal modulation of release and locomotor responses. The effects of dopaminergic and glutamatergic receptor selective ligands on dopamine and glutamate release as well as on locomotor responses are analyzed in the entire striatum, by reviewing both in vitro and in vivo data. Our purpose is not to cluster the dorsal and ventral striatum but more likely to highlight the differences and similarities between these two brain structures. Regarding in vivo data, only findings from focal injection studies in "intact" non-anesthetized animals are reviewed in order to focus on the intrinsic physiology of the striatum complex. 


\section{The striatum: caudate-putamen vs. nucleus accumbens}

The striatum is the main input structure of the basal ganglia and is a key component of the motor system. It is divided into the dorsal striatum, which includes the caudate and the putamen, and the ventral striatum that is mainly composed of the nucleus accumbens. The caudate-putamen and the nucleus accumbens show differences in their input and output projections.

The caudate-putamen is mainly innervated by the primary motor cortex, the anterior premotor and cingulate areas, the substantia nigra pars compacta and the retrorubral nucleus. The caudate-putamen in turn projects to the globus pallidus, the substantia nigra pars reticulata and pars compacta and the retrorubral nucleus.

The ventral striatum receives inputs from numerous prefrontal areas, limbic structures, such as the hippocampus and the amygdala, the ventral tegmental area and the retrorubral nucleus; in turn, the ventral striatum sends projections to the ventral pallidum, the substantia nigra pars compacta and reticulata, the retrorubral nucleus, the ventral tegmental area, and the hypothalamus $[88,96]$.

Therefore, while the dorsal striatum appears more allied with voluntary motor functions and is involved in the initiation, production and sequencing of motor behavior and in the development of addiction, the nucleus accumbens is more likely an interface between the limbic and the motor system and plays a major role in motivated and goaldirected behaviors as well as the development and expression of addiction $[88,96,145]$. However, there is no clear boundary between the caudate-putamen and nucleus accumbens.

The same neuronal cell types are present throughout the striatum. Striatal output neurons represent $95 \%$ of the striatal neurons and can be divided into two different subtypes: the striato-nigral GABAergic neurons and the striato-pallidal GABAergic neurons, which are characterized by containing different peptides and subtypes of dopamine receptors. The striatopallidal GABAergic neurons contain the peptide enkephalin and express the D2-like receptor, whereas the striato-nigral GABAergic neurons contain the peptides dynorphin and substance $P$ and express the D1-like receptor [5,66,114,238]. However, it is worthy to mention that these authors do not claim that striatal neurons that express one subtype of dopamine receptor cannot also express low levels of the other; but that the relative amount of D1-like and D2-like receptor subtypes varies dramatically according to the type of striatal output neurons that is considered. Thus, dopamine in fine differentially affects striato-nigral and striato-pallidal neurons as a consequence of the predominant expression of D1-like and D2-like receptors by these neurons. Nevertheless, in contrast with the dorsal striatum, where the vast majority of neurons that display D1-like receptors project to the substantia nigra, about $40-50 \%$ of neurons that express D1-like receptors in the nucleus accumbens project to the ventral pallidum [124,176]. But, like in the dorsal striatum, the vast majority of neurons that express D2-like receptors in the nucleus accumbens project to pallidum $[124,176]$. The second neuronal type found throughout the striatum is striatal interneurons, which represents $5 \%$ of the striatal neuronal population. Two subtypes of striatal interneurons can be found within the striatum: cholinergic interneurons and GABAergic interneurons [93]. 


\section{Localization of dopaminergic and glutamatergic receptors in the striatum complex (Fig. 1)}

\section{LOCALIZATION OF STRIATAL DOPAMINERGIC RECEPTORS}

Localization studies have shown that D1-like (D1 and D5) receptors are located at the postsynaptic level, mostly on medium spiny output GABAergic neurons. D2-like (D2, D3, and D4) receptors are located both at the presynaptic level, on dopaminergic neurons where they act as autoreceptors and on non-dopaminergic afferent fibers to the striatum among which are the glutamatergic terminals, and at the postsynaptic level on GABAergic output neurons $[14,77,139,187]$ (Fig. 1). In the caudate-putamen, all striato-nigral output neurons (100\%) express D1-like receptors in the caudate-putamen while only $5 \%$ of the striato-pallidal GABAergic output neurons express them [66,238]; conversely, all striato-pallidal GABAergic output neurons express D2-like receptors, while only $5 \%$ of the striato-nigral GABAergic output neurons express them $[66,83,114,115]$. Although a similar anatomical distribution is found in the nucleus accumbens [114], approximately 40 - 50\% of the striato-pallidal GABAergic neurons, mainly originating from the shell of the nucleus accumbens rather than from the core, express D1-like receptors $[124,176]$. Taken together, these data have provided the anatomical basis on the modulatory role of D1-like-and D2-like postsynaptic dopaminergic receptors on the activity of the striato-nigral GABAergic output neurons (that constitute the striato-nigral direct pathway) and of the striato-pallidal GABAergic output neurons (that is the first synaptic link of the striato-nigral indirect pathway), respectively [66,114,115,124,176].

At the receptor subtype level, D1, D2, and D5 receptors are expressed both in the caudateputamen and in the nucleus accumbens. Although D3 receptors are poorly expressed in the caudate-putamen [20,193], they are largely distributed in the nucleus accumbens $[20,50,51,112,113,115,117]$. In contrast, only moderate and low levels of D4 receptors are found in the caudate-putamen and nucleus accumbens, respectively [173]. Moreover, localization of D2 and D5 receptors has been also demonstrated on cholinergic and GABAergic interneurons $[4,7,14,100,116,125,162,236,237]$. Although there is some controversy about the dopaminergic receptor subtypes that are expressed on striatal glutamatergic terminals, either D2 receptors [36] or D4 receptors $[13,205,208]$, there is, however, a general consensus as far today that the receptors involved in the control of glutamate release throughout the striatum belong to the D2like, but not D1-like, receptor family. 


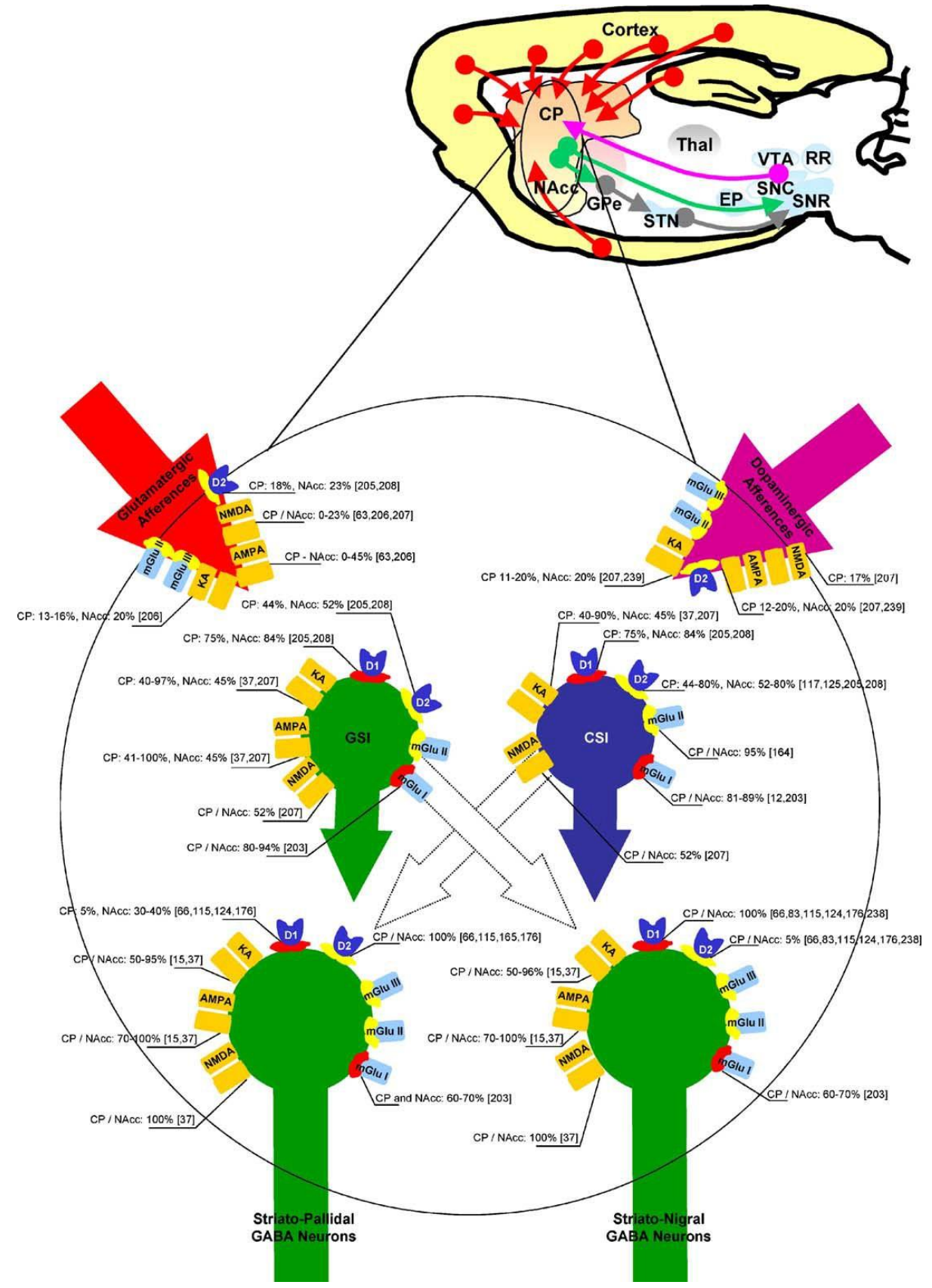

Fig. 1. Localization and relative abundance of D1-like and D2-like dopaminergic receptors; group I, group II and group III glutamatergic metabotropic receptors; and NMDA-, AMPA-and kainate glutamatergic ionotropic receptors in the caudate-putamen (CP) and nucleus accumbens (NAcc) on glutamatergic terminals arising from the cortex, the hippocampus and the amygdala (red arrow), on dopaminergic terminals arising from the retrorubral nucleus (RR), the substantia nigra pars compacta (SNC), and the ventral tegmental area (VTA; pink arrow), on GABAergic (green arrow) projection neurons and on GABAergic (green arrow; GSI) and cholinergic (blue arrow; CSI) striatal interneurons. AMPA: AMPA ionotropic glutamatergic receptors; D1: D1-like dopaminergic receptors; D2: D2-like dopaminergic receptors; EP: entopendocular nucleus; GPe: globus pallidus; KA: Kainate ionotropic glutamatergic receptors; mGlu I: group I metabotropic glutamatergic receptors; mGlu II: group II metabotropic glutamatergic receptors; mGlu III: group III metabotropic glutamatergic receptors; NMDA: NMDA ionotropic glutamatergic receptors; SNR: substantia nigra pars reticulata; STN: subthalamic nucleus; Thal: Thalamus. 


\section{LOCALIZATION OF STRIATAL IONOTROPIC GLUTAMATERGIC RECEPTORS}

Localization studies of iGlu receptors suggested that NMDA-and AMPA/kainate iGlu receptors are expressed presynaptically in dopaminergic [62,205-207,239] and glutamatergic terminals [205-207], but also postsynaptically in striatal medium spiny projection neurons $[15,69,205-$ 207] where they produce postsynaptic excitatory currents [146]. However, iGlu receptors are not located uniformly within the nucleus accumbens: while AMPA and kainate, as well as NMDA, receptors are expressed on the glutamatergic fibers arising from the cortex, only kainate and NMDA receptors, but not AMPA receptors, are expressed on the glutamatergic terminals arising from the hippocampus [205-207]. Moreover, a recent study has shown that AMPA receptors, but not NMDA receptors, are located on glutamatergic terminals arising from the cortex and the thalamus [63]. While NMDA and kainate receptors are also expressed on cholinergic and GABAergic striatal interneurons, AMPA receptors are expressed almost exclusively by GABAergic striatal interneurons [37,202].

\section{LOCALIZATION OF STRIATAL METABOTROPIC GLUTAMATERGIC RECEPTORS}

Over the last decade, histological studies have revealed that mGlu receptors are densely distributed within the striatum [3]. Although the vast majority (90\%) of mGlu receptors is thought to be located postsynaptically since lesion of corticostriatal projections only results in a little effect on mGlu receptor binding quantity [230], studies utilizing lesion techniques or presynaptic markers have shown that mGlu2, mGlu3 (group II), mGlu4 and mGlu7 (group III) receptors, but not mGlu1 and mGlu5 (group I) receptors, are located at the presynaptic level on glutamatergic and/or dopaminergic terminals [24,25,105, 158,204,211].

In striatal output neurons, in situ hybridization and immunohistochemistry studies have demonstrated the presence of high levels of mGlu5 receptors [133,188,189,209] and low levels of mGlu1 receptors [105,209]. Interestingly, like D1-like and D2-like receptors, mGlu1 and mGlu5 receptors seem well segregated in striatal projection neurons: mGlu1 receptors are primarily present on striato-nigral output neurons whereas mGlu5 receptors are primarily expressed in striatopallidal projection neurons [98,210]. Similarly, mGlu3 (group II) and mGlu7 (group III) receptors show high levels of expression in striatal output neurons whereas mGlu2 (group II) and mGlu4 (group III) receptors only exhibit low levels of expression [24,25,105,133, $150,209]$. Moreover, co-localization of mGlu1, mGlu3, mGlu5, and/or mGlu7 receptors has been shown on striato-nigral neurons or striatopallidal neurons [98, 210,211]. In addition to projection neurons and oncoming glutamatergic and dopaminergic neurons, it has been shown that at least mGlu1, mGlu2, and mGlu5 receptors are also expressed by cholinergic and GABAergic interneurons [12,105,163,164,203,209].

At the subcellular level, both group I and group III mGlu receptor subtypes, which are, respectively, concentrated in perisynaptic sites and pre- and postsynaptic sites [13,201, 204], share similar ultrastructural localization close to neurotransmitter release sites, whereas group II receptor subtypes have no close association with synapses [204]. In addition, unlike iGlu receptors, mGlu receptor subtypes, except for mGlu4 receptors, seem preferentially associated with fibers rather than soma $[13,90,201]$. 


\section{Dopaminergic control of striatal dopamine and glutamate release (Table 1)}

\section{MODULATION OF STRIATAL DOPAMINE RELEASE BY STRIATAL DOPAMINERGIC RECEPTORS}

\section{DATA FROM IN VITRO AND EX VIVO STUDIES}

Neurochemical studies on synaptosomes or striatal slices have repeatedly reported that activation of D2 receptors by the D2 receptor agonist quinpirole reduced the release of evoked dopamine $[10,119,195,233]$ (Table 1). Ex vivo studies performed on slices of nucleus accumbens have evidenced that application of the D3 receptor agonist 7-OH-DPAT inhibited single pulse stimulated dopamine release in a concentration-dependent manner, and this inhibitory effect was partly blocked by the D2-like receptor antagonist haloperidol [155]. In addition, other data have revealed that activation of D1-like receptors can also decrease evoked dopamine release in the nucleus accumbens, while blockade of these receptors had no effect [10]. Finally, activation of both D1-like and D2-like receptors by the non-specific agonist apomorphine inhibited electrically stimulated dopamine release [155]. Taken together, these data supported the existence both of a direct inhibitory modulation of striatal dopamine release by D2-like autoreceptors and, given the lack of anatomical evidence for D1-like receptors on dopaminergic terminals $[14,77,139]$, of an indirect inhibitory modulation of striatal dopamine release by D1like receptors through feedback loops involving other neurotransmitters.

Table 1. Dopaminergic control of striatal dopamine and glutamate release

\begin{tabular}{|c|c|c|c|}
\hline & Inhibitory effect & No effect & Facilitaibry effect \\
\hline \multicolumn{4}{|c|}{ Madulation of striztal dopamine nelease by stiabal dopaminergic receptors } \\
\hline \multirow[t]{5}{*}{ In vitro and ex vivo studies } & Evoked dopamine release & Evoked dopamine release & \\
\hline & D2 agonist $[10,119,195,233]$ & D1 antagonist $[10]$ & \\
\hline & D3 agonist [155] & & \\
\hline & D1 aganist [10] & & \\
\hline & D1 agonist+ D2 agonist [155] & & \\
\hline \multirow[t]{3}{*}{ In vivo studies } & D2 agonist $[79,213,222]$ & D2 antagonist [79] & D1 antagonist $[79,80,164]$ \\
\hline & D3 agonist $[49,65]$ & D1 agonist [80] & D2 antagonist $[79,80,164]$ \\
\hline & D1 agonist [79] & & \\
\hline \multicolumn{4}{|c|}{ Modulation of striztal gitutamate release by striztal dopaminergic neceptars } \\
\hline \multirow[t]{4}{*}{ In vitro and ex vivo studies } & KCl-evoled glutamate release & Basal glutamate release & KClevoked glutamate release \\
\hline & Dopamine $[42,135]$ & Dopamine [42] & Dopamine agonist [72] \\
\hline & Dopaminergic agonists $[72,177]$ & $\mathrm{KCl}$-evoked glutamate release & \\
\hline & D2 aganist [135] & D1 agonist [135] & \\
\hline In vivo studies & D2 agonist $[55,234]$ & D1 agonist [234] & Dopamine agonist $[59,166]$ \\
\hline
\end{tabular}

\section{DATA FROM IN VIVO STUDIES (FIG. 2A)}

Consistent with an autoreceptor role of D2-like receptors, in vivo studies using brain microdialysis in freely moving animals have revealed that focal administration of D2-like receptor agonists in the caudate-putamen reduced striatal dopamine release [79,213,222], while infusion of D2-like receptor antagonists increased it [79] (Fig. 2A). Additional studies performed in the caudate-putamen and the nucleus accumbens have revealed that application of the D3 receptor agonist 7-OH-DPAT decreased dopamine release [49,65]. However, the lack of selective D3 antagonist precluded any firm conclusion whether or not the decrease in striatal dopamine release was attributable to D3 receptors or other subtypes of D2-like receptors [49]; 
in that way, data from knock-out mice lacking the D3 receptor suggested that this receptor is not involved in dopamine autoreceptor function [104]. Activation of D1-like receptors by SKF 38393 or CY 208243 was found to decrease and to have no effect on striatal dopamine release $[79,80]$. But, given that the inhibitory effect of SKF 38393 on striatal dopamine release was not counteracted by co-infusion of a D1-like receptor antagonist, it seems possible that this effect might be nonspecific [79]. Conversely, blockade of D1-like receptors or of D2-like receptors in the caudate-putamen or the nucleus accumbens increased striatal dopamine release $[79,80,168]$. Administration of a D1-like receptor antagonist might stimulate dopamine release in the striatal complex by blocking D1-like receptors on GABAergic output neurons, thereby mediating negative feedback regulation to the substantia nigra pars compacta or ventral tegmental area, and/or by blocking D1-like receptor-mediated inhibition of interneurons. Such interneuron mechanisms may involve cholinergic interneurons, since it has been demonstrated that activation of the D1-like receptors excites cholinergic interneurons [7]; therefore, if one considers that dopaminergic terminals can be tonically inhibited by acetylcholine possibly through M2 or M4 receptors [57], blockade of D1-like receptors located on cholinergic interneurons would release this inhibition. Alternatively, it should be noted that activation of D2-like receptors inhibits cholinergic interneurons [162], although others did not find any effect on basal acetylcholine release in the nucleus accumbens following activation or blockade of D2like receptors $[99,169]$. Given the anatomical distribution of dopaminergic receptors in the striatum complex, these results altogether are consistent with in vitro/ex vivo data of a direct inhibitory control of dopamine release by D2-like presynaptic autoreceptors and of an indirect control by D1-like receptors, likely acting through trans(poly)synaptic mechanisms [168].

\section{MODULATION OF STRIATAL GLUTAMATE RELEASE BY STRIATAL DOPAMINERGIC RECEPTORS}

\section{DATA FROM IN VITRO AND EX VIVO STUDIES}

Few in vitro and ex vivo studies are available on the effects of dopamine and dopaminergic receptor agonists and antagonists on glutamate release in the striatum. However, they repeatedly show that both in striatal slices and synaptosomes dopaminergic receptor activation has an inhibitory action on glutamate release. Perfusion of dopamine at high concentration (100 $\mu \mathrm{M})$ or of non-selective dopaminergic receptor agonists, such as apomorphine, inhibited KClevoked, but not spontaneous, glutamate release in striatal slices in a tetrodotoxin (TTX)insensitive way $[42,177]$. Similar results were obtained both from slices and synaptosomes, and involvement of D2-like receptors was proposed on the basis of selectivity towards D2-like receptor antagonists [140]. Further experiments found that apomorphine and haloperidol, which are non-selective dopaminergic receptor agonist and antagonist, respectively, inhibited and enhanced $\mathrm{KCl}$-evoked $\left[{ }^{3} \mathrm{H}\right]$ glutamate release from striatal slices [72], but other data did not report inhibitory modulation of $\mathrm{KCl}$-stimulated $\left[{ }^{3} \mathrm{H}\right]$ glutamate release in slices during perfusion with selective D1-like or D2-like receptor agonists [194]. This lack of effect might be explained by a high level of receptor occupancy by endogenous dopamine as shown by Peris et al. [157] who confirmed the inhibitory effect of D2-like receptor activation in experiments monitoring $\left[{ }^{3} \mathrm{H}\right] \mathrm{d}$-aspartate (a tracer of glutamatergic transmission) efflux. These data obtained from striatal 
slices were confirmed in a study using synaptosomal preparations showing that dopamine inhibited depolarization-evoked glutamate release via D2-like presynaptic receptors [135].

\section{DATA FROM IN VIVO STUDIES (FIG. 2A)}

Although a very few in vivo studies in the awake rat are available on the modulation of striatal glutamate release by striatal dopaminergic receptors, they confirm data from in vitro and ex vivo studies. Microdialysis studies employing D1-like and D2-like receptor agonists and antagonists showed that infusion of the D2-like receptor agonists quinpirole and LY 163502 in the striatum inhibited evoked glutamate release in a sulpiride (a D2-like receptor antagonist)-sensitive way $[55,234]$, whereas injection of the D1 selective receptor agonist SKF 38393 showed no effect [234]. Subsequent studies using the push-pull technique have also demonstrated that the mixed D1-D2 receptor agonist apomorphine increased spontaneous glutamate efflux in the nonanesthetized rat $[59,166]$. Overall, consistent with a presynaptic localization of D2-like, but not of D1-like, dopaminergic receptors on glutamatergic terminals in the striatum, in vivo studies confirm what was found in in vitro studies that D2-like, but not D1-like, receptors are involved in an inhibitory control of evoked glutamate release, but further suggest that D2-like dopaminergic receptors may also modulate spontaneous glutamate release. 

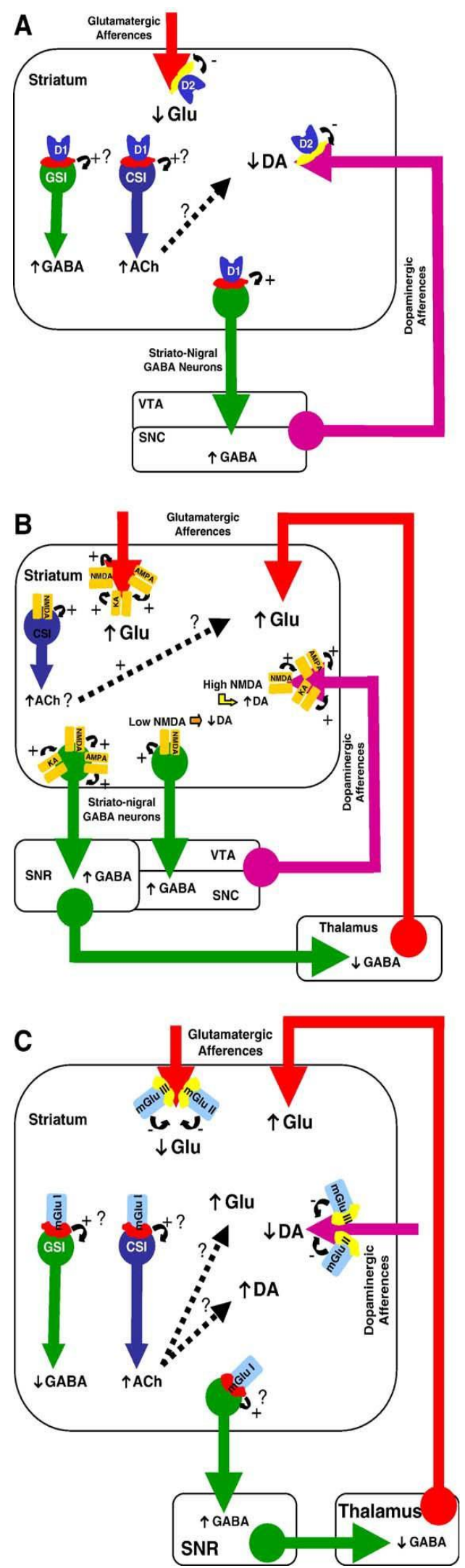

Fig. 2. (A) Illustration of the modulation of striatal dopamine- and glutamate release by striatal dopaminergic receptors. Taken together, data show a direct inhibitory control of dopamine release by D2-like autoreceptors and an indirect control by D1-like receptors, likely acting through trans(poly)synaptic mechanisms mediated via striatal interneurons and/or striato-nigral GABAergic output neurons. In addition, D2-like, but not D1-like, receptors are involved in an inhibitory control of glutamate release in the striatum. (B) Modulation of striatal dopamine and glutamate release by striatal ionotropic glutamatergic receptors. Ionotropic glutamatergic receptors might regulate glutamate release in the striatum by acting presynaptically although it is unclear how opening of ion-channel receptors may fit with a classical autoreceptor inhibitory mechanism; in fact, activation of ion-channel autoreceptors may favor release. In addition, trans(poly)synaptic striato-cortico-striatal mechanisms may be considered involving a positive feedback loop mediated through activation of postsynaptic NMDA receptors located on striato-nigral GABAergic projection neurons that may enhance glutamate release from corticostriatal and thalamostriatal afferents. Cholinergic interneurons might also play a key role in the positive regulation of striatal glutamate release. Alternatively, activation of NMDA receptors by physiological doses of NMDA inhibits striatal dopamine release and further leads to a concomitant increase of GABA release in the substantia nigra pars reticulata (SNR), suggesting the involvement of inhibitory feedback through the striato-nigro-thalamo-striatal loop. Such an inhibitory control of dopamine release in the striatum may overcome at higher NMDA receptor occupancy or high, possibly non-physiological, NMDA concentrations, leading to an increase in striatal dopamine release. Studies on AMPA and kainate receptors indicate that they exert a phasic facilitating effect on striatal dopamine release. (C) Modulation of striatal dopamine and glutamate release by striatal metabotropic glutamatergic (mGlu) receptors. Activation of group I mGlu receptors induces an increase in glutamate release. Given the lack of presynaptically located group I mGlu receptors within the striatum, it is likely that this facilitating effect results from trans(poly)synaptic mechanisms that may involve striato-nigral GABAergic output neurons and/or striatal interneurons. Indeed, group I mGlu receptors have been demonstrated to stimulate cholinergic striatal interneurons (CSI): the release of acetylcholine may favor indirectly that of glutamate. GABAergic striatal interneurons (GSI) might also been involved since blockade of group I mGlu receptors stimulates GABA striatal release and activation of these receptors inhibits GABA-mediated IPSCs in corticostriatal slices: this may inhibit glutamate release in the striatum. In contrast, activation of group II or group III mGlu receptors inhibits glutamate release, results consistent with a presynaptic localization of these receptors on glutamatergic terminals within the striatum. Regarding the modulation of striatal dopamine release by metabotropic glutamate receptors, activation of group I mGlu receptors induces an increase in striatal dopamine release, which effect may result, as seen above for glutamate release, from trans(poly)synaptic mechanisms. Activation of group II or group III mGlu receptors decreases striatal dopamine, result consistent with a presynaptic localization of these receptors on dopaminergic fibers within the striatum. Ach: acetylcholine; AMPA: AMPA ionotropic glutamatergic receptors; D1: D1-like dopaminergic receptors; D2: D2-like dopaminergic receptors; DA: dopamine; Glu: glutamate; KA: Kainate ionotropic glutamatergic receptors; mGlu I: group I metabotropic glutamatergic receptors; mGlu II: group II metabotropic glutamatergic receptors; mGlu III: group III metabotropic glutamatergic receptors; NMDA: NMDA ionotropic glutamatergic receptors; SNC: substantia nigra pars compacta; SNR: substantia nigra pars reticulata; VTA: ventral tegmental area. 


\section{Glutamatergic control of striatal glutamate and dopamine release}

\section{MODULATION OF STRIATAL GLUTAMATE AND ASPARTATE RELEASE BY STRIATAL IGLU RECEPTORS (FIG. 2B)}

Ex vivo studies on striatal slices have reported that application of agonists of AMPA/kainate receptors stimulated basal d-aspartate release, while activation of NMDA receptors had no effect [53] (Tables 2 and 3).

In vivo studies by means of microdialysis have reported consistently a facilitating effect of NMDA- and AMPA/kainate receptor agonists on glutamate and aspartate release $[16,30,156,235]$, an effect that so far as NMDA receptors are concerned was blocked by pretreatment or co-administration of the non-competitive NMDA receptor antagonists MK-801 and phencyclidine $[30,235]$. In contrast, whether or not NMDA receptor antagonists may modulate glutamate release in the striatum is more controversial; indeed, while local infusion of MK-801 at $100 \mu \mathrm{M}$ increased both aspartate and glutamate release in the striatum [30], MK-801 at the dose of $75 \mu \mathrm{M}$ or phencyclidine at $1 \mathrm{mM}$ did not [30,235]. However, since this facilitating effect has only been reported at high doses of MK-801, the observed effect might be unspecific and not be due to NMDA receptor blockade. Additionally, both the NMDA receptor antagonist CPP and the AMPA receptor antagonist LY 293558 attenuated the increase in glutamate release produced by the glutamate transporter inhibitor L-trans-PDC, without altering basal glutamate levels [171].

Although iGlu receptors might regulate glutamate release in the striatum by acting presynaptically, it is unclear how opening of ion-channel receptors may fit with a classical autoreceptor mechanism. However, one can presume that activation of iGlu receptors located at the presynaptic level would facilitate depolarization, which in turn would increase release of stored neurotransmitters in the vicinity of these activated receptors (consistent with what the bulk of the data show). This might be some kind of a "feed-forward" amplification function or a mechanism for amplifying certain signals when glutamatergic afferents are active $[30,53,120,156]$. Alternatively, since the issue of presynaptic iGlu receptors is controversial $[15,69]$, the possibility has also been considered of a trans(poly)synaptic striato-cortico-striatal positive feedback loop, in which activating postsynaptic NMDA receptors would enhance action potential-dependent glutamate release from corticostriatal and thalamostriatal afferents through the substantia nigra and the thalamus [171,235]. Finally, cholinergic interneurons might also play a key role in the regulation of glutamate release. For instance, it has been demonstrated that activation and blockade of NMDA receptors in the dorsal striatum induced an increase and a decrease of striatal acetylcholine release, respectively [103]. Therefore, it is possible that such changes in striatal acetylcholine release may modulate in fine glutamate release. 
Table 2. Control of striatal dopamine and glutamate release by ionotropic glutamatergic receptors

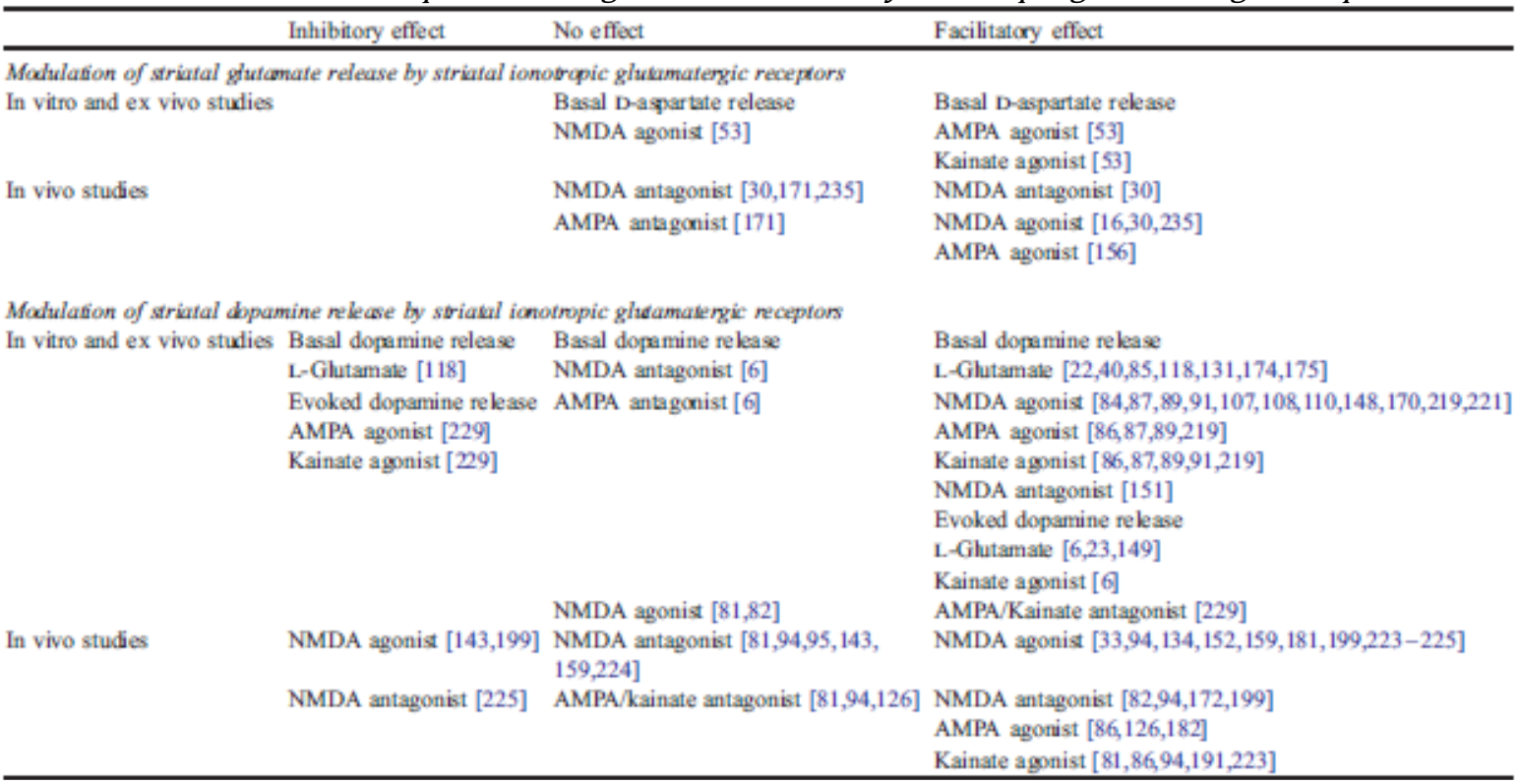

Table 3. Control of striatal dopamine and glutamate release by metabotropic glutamatergic receptors

\begin{tabular}{|c|c|c|c|}
\hline & Inhibitory effect & No effect & Facilitatory effect \\
\hline \multicolumn{4}{|c|}{ Modulation of striatal glutamate release by striatal mewhotropic glutamatergic neceptors } \\
\hline \multirow[t]{3}{*}{ In vitro and ex vivo studies } & Evoked glutamate release & Evoked glutamate release & \\
\hline & Group I/II agonist [121-123] & Group III agonist [121] & \\
\hline & Group II agonist $[121,122]$ & & \\
\hline \multirow[t]{4}{*}{ In vivo studies } & Group II agonist $[41,76,231]$ & & Group I/II agonist [120] \\
\hline & Group III agonist [232] & & Group I agonist $[161,198]$ \\
\hline & & & Group II antagonist $[41,76,231]$ \\
\hline & & & Group III antagonist [232] \\
\hline \multicolumn{4}{|c|}{ Modulation of striatal dbpamine nelease by striabal metabotropic glubumatergic receptors } \\
\hline \multirow[t]{6}{*}{ In vitro and ex vivo studies } & Evoked dopamine release & Basal dopamine release & Basal dopamine release \\
\hline & Group I agonist [240] & Group I/II antagonis [6] & Group I/II agonist [6] \\
\hline & & Evoked dopamine release & \\
\hline & & Group II agonist [240] & \\
\hline & & Group III agonist [240] & \\
\hline & & Group I antagonist [240] & \\
\hline \multirow[t]{6}{*}{ In vivo studies } & Basal dopamine release & Basal dopamine release & Basal dopamine release \\
\hline & Group II agonist $[70,76]$ & mGluRS antagonist [67] & Group I/II agonist $[8,27,152,216]$ \\
\hline & Group III agonist $[76,130]$ & & Group I agonist [27] \\
\hline & Evoked dopamine release & & Group II agonist [27] \\
\hline & Group I/II agonist [216] & & Group II antagonist [76] \\
\hline & & & mGluRS antagonist [67] \\
\hline
\end{tabular}

\section{MODULATION OF STRIATAL DOPAMINE RELEASE BY STRIATAL IGLU RECEPTORS}

\section{DATA FROM IN VITRO AND EX VIVO STUDIES}

In vitro investigations have reported the facilitating action of NMDA, AMPA and kainate on spontaneous $\left[{ }^{3} \mathrm{H}\right]$ dopamine release in synaptosomes, which facilitating action was inhibited by competitive and non-competitive iGlu receptor antagonists $[89,108,219]$. In this model, NMDA and AMPA/kainate receptors work together to increase dopamine release, since AMPA/kainate receptor activation leading to membrane depolarization produces the removal of the voltagedependent $\mathrm{Mg}^{2+}$ block and subsequently the NMDA channel opening [38,48]. 
Early observations from ex vivo studies on striatal slices have found that application of Lglutamate at millimolar concentrations increased spontaneous dopamine release in the striatum in a $\mathrm{Mg}^{2+}$-dependent way $[22,40,85,174,175]$; simultaneous application of a depolarizing stimulus, either $\mathrm{KCl}$ or electrical stimulation, potentiated the facilitating effect of L-glutamate on dopamine release and further lowered the threshold of L-glutamate effective concentrations from the millimolar to the micromolar range $[6,23,178]$. While in the absence of $\mathrm{Mg}^{2+}$, the effect of exogenously applied L-glutamate on spontaneous or evoked dopamine release was primarily mediated by NMDA receptors [6,149], in the presence of $\mathrm{Mg}^{2+}$ the effect of L-glutamate on electrically evoked dopamine release was mainly mediated by AMPA/ kainate receptors [6]. Similar findings were repeated afterwards with NMDA- and AMPA/kainate receptor agonists. Application of NMDA at micromolar concentrations $(15-100 \mu \mathrm{M})$ or various iGlu receptor agonists was found to facilitate dopamine release [84,86,87,107,110,148,170,221]; in addition, submicromolar concentrations of NMDA or AMPA were further reported to potentiate dopamine release induced by high-frequency tetanic stimulation [149]. The NMDA effect was observed only in the absence of $\mathrm{Mg}^{2+}$. Evidence for a NMDA receptor involvement in the control of dopamine release has been also reported in slices from the nucleus accumbens [91,131]. Studies with tetrodotoxin confirmed localization studies from a functional perspective that NMDA and AMPA/kainate receptors are located both presynaptically and postsynaptically in the striatum $[31,40,85,87,109,131,147,192]$. This excitatory effect of iGlu receptor agonists on dopamine release appears to be impulse-independent, since these compounds increase extracellular dopamine levels even after the cessation of impulse activity induced by application of tetrodotoxin $[84,87,108,110]$. Alternatively, although a few inhibitory $[23,85]$ and excitatory effects [151] were observed, most studies performed ex vivo found that NMDA and AMPA receptor antagonists were ineffective at modulating spontaneous dopamine outflow in the striatum [6]. Altogether, these data rule out the existence of a glutamate-mediated facilitating tone on striatal dopamine release, and suggests that NMDA and AMPA/kainate receptors would exert a phasic facilitating control on striatal dopamine release.

However, in contrast with the facilitating effect of glutamate and iGlu receptor agonists on both spontaneous and evoked dopamine release in the striatum, there is a growing body of evidence that activation of iGlu receptors in the striatum may be inhibitory towards evoked dopamine release that is impulse-dependent (meaning that an impulse activity is necessary for dopamine release so that tetrodotoxin can counteract the effect on dopamine release) [84,229]. Data have shown in the presence of $\mathrm{Mg}^{2+}$ that application of the iGlu receptor agonist AMPA $(100 \mu \mathrm{M})$ or kainate (10 AM- $1 \mathrm{mM}$ ) decreased evoked dopamine release in the striatum and that this effect was blocked by the non selective iGlu receptor antagonist kynurenate $(100 \mu \mathrm{M})$, which by itself increased evoked dopamine release [229]. In the absence of $\mathrm{Mg}^{2+}$, a similar decrease in evoked dopamine release was observed following application of NMDA at 20,50, and $100 \mu \mathrm{M}$, and this effect was blocked by the selective NMDA receptor antagonist AP5 [84,229]. Therefore, given these data and the considerable amount of evidence (see data above) that glutamate has excitatory effects on striatal dopamine release, it is likely that iGlu receptors may regulate both impulse dependent and impulse independent dopamine release in the striatum in a facilitatory and inhibitory fashion. 


\section{DATA FROM IN VIVO STUDIES (FIG. 2B)}

Microdialysis investigations gave rise to similar controversial data. While high NMDA concentrations $(0.3-10 \mathrm{mM})$ were consistently reported to increase dopamine release within the striatum $[33,94,95,134,152,159,181,199,223,224]$, lower concentrations $(10-100 \mu \mathrm{M})$ were reported to inhibit $[143,199]$, to increase [226], or to leave unchanged $[81,82]$ dopamine release in the caudate-putamen or the nucleus accumbens. The inhibitory effect on dopamine release of low NMDA concentrations was associated with a concomitant increase in GABA release in the substantia nigra pars reticulata [143], which suggests the involvement of a feedback inhibitory control through the striato-nigro-striatal loop. Such an inhibitory control of striatal dopamine release, which may occur through activation of intra- and/or extrastriatal inhibitory loops, may be predominant at low NMDA receptor occupancy and overcome at higher NMDA receptor occupancy or high NMDA concentration. Accordingly, inhibitory and stimulatory effects at low NMDA concentrations were observed when NMDA was perfused for short (i.e., $10 \mathrm{~min}$ ) or longer (at least $30 \mathrm{~min}$ ) time, respectively [143,199,226]. Regarding NMDA antagonists, most studies found that local perfusion of competitive or non-competitive NMDA receptor antagonists at micromolar concentrations failed to alter spontaneous dopamine release within the striatum ([81,94, 143,159,224], but [226]). Exceptions to these observations utilized the non-competitive NMDA receptor antagonist MK-801 at micromolar concentrations [82,199] or other NMDA receptor antagonists at high millimolar concentrations that may be non-selective [94,118,172] and reported that blocking NMDA receptors resulted in an increased dopamine release in the caudate-putamen and the nucleus accumbens. The agonist data and the low-dose antagonist data taken together suggest that NMDA receptors would exert a phasic excitatory control on striatal dopaminergic release (meaning that NMDA receptors are not always activated and when they are they stimulate dopamine release).

When dopamine release in the striatum is evoked by local infusion of the dopamine uptake blocker nomifensine [142] or electrical stimulation of the glutamatergic pathway that projects from the ventral subiculum to the nucleus accumbens [200], NMDA and AMPA/kainate receptor antagonists decrease striatal dopamine release. These data suggest that, depending on the level of striatal dopaminergic and/or glutamatergic activity, NMDA receptors may exert a tonic facilitatory control on dopamine release in the striatum.

Studies on AMPA and kainate receptors in the striatum consistently found that perfusion of AMPA or kainate in the micromolar range had a facilitatory effect on dopamine release in the striatum $[81,87,94,126,182,191,223]$, while perfusion of AMPA/kainate receptor antagonists failed to alter spontaneous dopamine release $[81,94,126]$. This indicates that AMPA/kainate receptors would exert a phasic facilitating effect on dopamine release in the striatum. 


\section{MODULATION OF STRIATAL GLUTAMATE RELEASE BY STRIATAL MGLU RECEPTORS}

\section{DATA FROM EX VIVO STUDIES}

Despite the availability of Fgroup selective_ mGlu receptor ligands, very few data are available on the effects of mGlu receptors on striatal release of excitatory amino acids ex vivo. The effects of the group I/group II mGlu receptor agonist (1S,3R)-1-aminocyclopentane-1,3-dicarboxylic acid (ACPD), the group II mGlu receptor agonist (2S,3S,4S)-a-carboxycyclo-propylglycine (LCCG-I), and the group III mGlu receptor agonist 2-amino-4-phosphono-butyrate (L-AP4) were studied in rat striatal slices on $\mathrm{KCl}$-induced release of $\left[{ }^{3} \mathrm{H}\right]$-glutamate and $\left[{ }^{3} \mathrm{H}\right] \mathrm{d}$-aspartate $[121-$ 123]. Even at high concentrations up to $300 \mu \mathrm{M}$, L-AP4 had no effect, result that contrasts with anatomical data and further questions the functional role of group III mGlu receptors located presynaptically on glutamatergic terminals within the striatum. In contrast, L-CCG-I (EC50 $=0.5$ $\mu \mathrm{M})$ and ACPD $(\mathrm{EC} 50=100 \mu \mathrm{M})$ reduced the $\mathrm{KCl}$-induced increase in $\left[{ }^{3} \mathrm{H}\right]$-glutamate, newly synthesized from $\left[{ }^{3} \mathrm{H}\right]$-glutamine, and $\left[{ }^{3} \mathrm{H}\right] \mathrm{d}$-aspartate release. Given that group I mGlu receptors are not expressed in glutamatergic fibers afferent to the striatum, the effect induced by ACPD may be attributed in agreement with the action of L-CGI to group II mGlu receptor activation.

\section{DATA FROM IN VIVO STUDIES (FIG. 2C)}

Early investigations using in vivo microdialysis in freely moving rats found that mGlu receptor stimulation with the non-selective mGlu receptor agonist ACPD at relatively high concentrations increased basal glutamate release in the striatum [120]. Then, further experiments were conducted afterwards with selective mGlu receptor agonists and antagonists. In agreement with the data obtained from ex vivo studies, in vivo microdialysis investigations using group-selective mGlu receptors ligands have demonstrated a specific modulation of glutamate release in the striatum. Intrastriatal infusion of the group I mGlu receptor agonist DHPG or the mGlu5 receptor agonist (RS)-2-chloro-5-hydroxyphenylglycine (CHPG) induced an increase in glutamate release $[161,198]$ that was blocked by either group I mGlu receptor antagonists or the mGlu5 receptor antagonist MPEP [161]. Given the lack of presynaptically located group I mGlu receptors within the striatum, it may be suggested that the facilitating effect of group I mGlu receptor agonists on striatal glutamate release resulted from trans(poly)synaptic mechanisms. Such mechanisms may involve striatal cholinergic or GABAergic interneurons since group I mGlu receptors are also expressed on these interneurons [12]. In addition, electrophysiological data showed that group I mGlu receptors stimulate striatal cholinergic interneurons [163], which may in fine stimulate glutamate release. GABAergic interneurons might also been involved since blockade of group I mGlu receptors stimulates striatal GABA release in vivo [11] and that activation of group I mGlu receptors inhibits GABA-mediated IPSCs in corticostriatal slices [11]. Therefore, GABAergic interneurons may tonically inhibit corticostriatal glutamatergic terminals and activating group I mGlu receptors may release this inhibition.

In contrast, intrastriatal perfusion of the group II mGlu receptor agonists APDC, DCG-IV, L-CCG-I produced a decrease in glutamate release [41,76,231], results consistent with a presynaptic location of group II mGlu receptors on glutamatergic terminals within the striatum. Conversely, intrastriatal infusion of group II receptor antagonists resulted in an increase in striatal 
glutamate release $[41,76,231]$ that suggests that group II mGlu receptors are tonically active at inhibiting glutamate release in the striatum. Group III mGluRs have also been demonstrated to control glutamate release in the nucleus accumbens. While activation of group III mGlu receptors decreased the extracellular level of glutamate, blockade of group III mGlu receptors increased it [232].

\section{MODULATION OF STRIATAL DOPAMINE RELEASE BY STRIATAL MGLU RECEPTORS}

\section{DATA FROM EX VIVO STUDIES}

Weak evidence for an involvement of mGlu receptors in the control of striatal dopamine release ex vivo has been so far produced. The group I/group II mGlu receptor agonist ACPD has been demonstrated to stimulate spontaneous [3H]dopamine release in the presence of physiological concentration of $\mathrm{Mg}^{2+}(1.2 \mathrm{mM})$, which facilitating effect was blocked by the group I/group II mGlu receptor antagonist a-methyl-4-carboxyphenylglycine (MCPG) that showed no effect by itself when injected alone [6]. Given the lack of anatomical evidence of group I mGlu receptors on dopaminergic terminals that project to the striatum, this effect may be attributed to group II mGlu receptors located presynaptically on dopaminergic fibers afferent to the striatum that may exert a phasic facilitating control on striatal dopamine release. However, the meaning of these findings remains to be further investigated, since activation of mGlu receptors by ACPD did not seem to contribute to the facilitating effect of exogenously applied L-glutamate in the presence of $\mathrm{Mg}^{2+}$ on striatal dopamine release [6].

A recent study performed on corticostriatal slices demonstrated that activation of group I mGlu receptors, but not of group II or group III mGlu receptors, produced a dosedependent reduction of stimulated dopamine release; while blockade of group I mGlu receptors had no effect [240].

\section{DATA FROM IN VIVO STUDIES (FIG. 2C)}

Studies using in vivo microdialysis in freely moving rats revealed that mGlu receptor stimulation with the non-selective mGlu receptor agonist ACPD in the micromolar range increased dopamine release in the striatum $[8,27,152,216]$. In contrast to its facilitating effect on basal dopamine release and as reported above for glutamate, mGlu receptor stimulation was found to produce an inhibitory action on evoked striatal dopamine release, as revealed by the inhibitory action of ACPD on KCl-evoked dopamine release in the striatum [216]. Then, further experiments were conducted afterwards with selective mGlu receptor ligands. Administration of the group I mGlu receptor agonist DHPG induced an increase in striatal dopamine release [27]. Given the lack of presynaptically located group I mGlu receptors within the striatum, this facilitating effect on dopamine release may result, like glutamate release produced by group I mGlu receptor agonists, from trans(poly)synaptic mechanisms. An increase of striatal dopamine release has also been reported following application in the striatum of the mGluR5 agonist MPEP, but only at high dose $(500 \mu \mathrm{M})$, which may reflect non-specific mechanism [67]. Otherwise, while infusion in the striatum of the group II mGlu receptor selective agonists led to a decrease in striatal dopamine ([70,76] but [27]), result consistent with a presynaptic location of group II mGlu receptors on dopaminergic fibers within the striatum, intrastriatal infusion of 
group II receptor antagonists resulted in an increase in striatal dopamine [76]. This suggests that group II mGlu receptors would be tonically active at inhibiting dopamine release from nigrostriatal and mesostriatal terminals in the striatum. Other investigations revealed that group III mGlu receptors, like group II mGlu receptors, would also possess an inhibitory tonic action on striatal dopamine release [76,130], result consistent with both behavioral (see below) and anatomical data of a localization of group III mGlu receptors on dopaminergic terminals within the striatum area.

\section{Behavioral motor intrinsic effects and interactions of striatal dopaminergic and glutamatergic receptors}

\section{BEHAVIORAL MOTOR RESPONSES PRODUCED BY STRIATAL DOPAMINERGIC RECEPTORS (TABLE 4; FIG. 3A)}

The functional and behavioral effects of dopamine and dopamine receptor agonists and antagonists have been extensively investigated (Fig. 3A, Table 4). Injection of the D1-like receptor agonist SKF $38393(0.3-10 \mu$ g, i.e., $0.9-30 \mu \mathrm{mol})$ in the nucleus accumbens induced a dosedependent increase in locomotor activity [39,44 - 47,56,68,137,138,197,227], which is assumed to reflect the predominant control of the direct pathway by D1-like receptors . Only rare studies show no effect on locomotion after injection of the D1 receptor agonist SKF 38393 in the nucleus accumbens $[141,165]$ or of the D1 receptor agonist fenoldopam in the caudateputamen [136]. Conversely, application of a specific D1-like receptor antagonist in the nucleus accumbens $[137,153,165]$ or in the caudate-putamen [153] has been shown to decrease locomotor activity.

The physiology of D2-like receptors in the striatum appears more complex, probably due to the permissive, enabling, role of D1-like receptors on postsynaptic D2-like receptors activation $[217,218,225]$, which mechanisms are still not elucidated. As a consequence, it is generally assumed that the effects observed following D2-like receptor agonist administration reflect dopaminergic processes placed under the control of D2-like autoreceptors. Consistent with a presynaptic localization of D2-like receptors on dopaminergic terminals arising from the substantia nigra and the ventral tegmental area, and in accord with the decrease in striatal dopamine release produced by D2-like receptor activation [79], administration in the nucleus accumbens of the D2-like receptor agonists LY 171555 (also named quinpirole; 1 - $15 \mu$ g, i.e., 4$60 \mu \mathrm{mol})$, PD 128907 (0.5- $5 \mathrm{Ag}$, i.e., $1.75-17.5 \mu \mathrm{mol}$ ) or of 7-OH-DPAT (2.5- $5 \mu \mathrm{g}$, i.e., 7.5 - 15 $\mu \mathrm{mol})$ has been repeatedly found to decrease motor activity $([32,39,44-47,141,197]$ but [136]). However, depending on the dose used, others have found either a decrease or an increase in locomotor activity following administration of D2-like receptor agonists. Thus, infusion of LY171555 in the nucleus accumbens or in the caudate-putamen of awake rats has been reported to induce a biphasic effect with low doses $(0.1$ to $3 \mu \mathrm{g}$, i.e., $0.4-12 \mu \mathrm{mol})$ producing an increase in locomotor activity and high doses (5 to $40 \mu \mathrm{g}$, i.e., 20-160 $\mu \mathrm{mol}$ ) a reduction of locomotor activity [56,60,68,215], although others have found opposite dose-dependent effects with the D2-like receptor agonist PD 128907 [167]. Finally, only rare studies found no significant effect on locomotor activity following activation of D2-like receptors [165]. These discrepancies may 
depend on the level of basal locomotor activity and on D2-like autoreceptor occupancy [227]. Conversely, focal injection of D2-like receptor antagonists in the nucleus accumbens or the caudate-putamen resulted in a decrease in motor activity [74,153,165,214], which is assumed to reflect striatal postsynaptic mechanisms.

Whatever the compounds used, behavioral (but also electrophysiological) studies have repeatedly demonstrated that D1-like receptors and D2-like receptors exert synergistic effects. Co-infusion of D1-like and D2-like receptor agonists in the nucleus accumbens or the caudate putamen, a pharmacological condition thought to activate both striatal D1-like receptors and presynaptic and postsynaptic D2-like receptors [1,2,217,218,225], was consistently found to result in a dramatic increase in locomotor activity compared to the behavioral effect produced by administration of D1-like receptor agonists alone [32,39,43-47,56,58,68,78,92,165].

\section{BEHAVIORAL MOTOR EFFECTS OF STRIATAL IGLU RECEPTORS (TABLE 5B)}

\section{INTRINSIC BEHAVIORAL MOTOR RESPONSES PRODUCED BY IGLU RECEPTORS (FIG. 3B)}

\section{Behavioral motor effects of NMDA receptors}

Studies on the locomotor effects of NMDA iGlu receptor agonists consistently found that the NMDA receptor agonist NMDA had a facilitating action on locomotor activity, when given in the nanomolar range (7- $70 \mathrm{nmol} . / \mathrm{side}$, i.e., 1 - $10 \mu \mathrm{g} / \mathrm{side})$ in the caudate-putamen ([181,212] but [183]) or the nucleus accumbens $[18,29,47,54,71,228]$ (Table 5). Similar locomotor effects were found following injection in the nanomolar range (1- $50 \mathrm{nmol} . / \mathrm{side}$, i.e., $0.2-10 \mu \mathrm{g} / \mathrm{side}$ ) of the NMDA receptor antagonists AP5 and AP7 in the nucleus accumbens $[29,47,97,154]$ and the caudate- putamen $[183,212]$. These effects of NMDA on locomotor activity can be attributed to NMDA receptor mechanisms. Indeed, administration in the caudate-putamen of AP7 at a subefficient dose of $0.5 \mathrm{nmol}$. $(0.1 \mu \mathrm{g})$, which produced no effect by itself on locomotor activity, blocked the increase in locomotor activity induced by intrastriatal administration of NMDA [212]. Similar findings were found with the NMDA receptor antagonist AP5. Administration in the nucleus accumbens of AP5 at subefficient doses in the nanomolar range (1- 15 nmol, i.e., 0.2 $-3 \mu \mathrm{g} / \mathrm{side}$ ) led to a reduction of the NMDA-induced increase in locomotor activity $[47,71]$, but showed no effect on the increase in locomotor activity produced by AMPA [47]. Understanding and explaining such results, i.e., that agonists and antagonists of NMDA receptors both induce an increase in locomotor activity, represents a major challenge that is still unresolved. However, several hypotheses that are not mutually exclusive may emerge regarding such an apparent paradox: subpopulations of functionally distinct NMDA receptors could be involved, possibly composed of different subunits, located on different pathways and/or activated in a different fashion (either tonically or phasically). But, clearly, much more studies combining neuropharmacological and immunohistochemical approaches are needed to understand thoroughly the modulation of striatal activity by NMDA receptors.

\section{Behavioral motor effects of AMPA/kainate receptors}

A similar locomotor activation was found following injection in the nanomolar range of the agonist AMPA (0.1-2.5 nmol/side, i.e., 0.02-0.5 $\mu \mathrm{g} / \mathrm{side}$ ) and antagonist CNQX (2-3 nmol./side, i.e., $0.6-1 \mu \mathrm{g} / \mathrm{side})$ in the nucleus accumbens $[19,29,47,54,75,190,228]$. Other data in contrast 
found no effect on locomotor activity following injection of CNQX in the nucleus accumbens, but confirmed that blockade of AMPA/kainate receptors by NBQX, which preferentially acts at AMPA receptors relative to kainate receptors, produced an increase in locomotor activity [39]. The locomotor-activating properties of AMPA were found to be selective. Administration in the nucleus accumbens of the AMPA/kainate receptor antagonist CNQX at $3 \mathrm{nmol} . /$ side $(1 \mu \mathrm{g} / \mathrm{side})$ decreased the locomotor activity produced by AMPA, but not that produced by NMDA [47]; similar findings were found with the AMPA/kainate receptor antagonist GAMS that preferentially acts at AMPA receptors relative to kainate receptors [190].

Table 4. Behavioral motor effects of dopaminergic receptors

\begin{tabular}{llll}
\hline Inhibitory effect & No effect & Facilitatory effect & Biphasic effect \\
\hline D1 antagonist [137,153,165] & D1 agonist [136,141,165] & D1 agonist [39,44-47, & D2 agonist: Low doses/stimulating effect; \\
& & $56,68,137,138,195,227]$ & high doses/inhibiting effect [56,60,68,215] \\
D2 agonist [32,39,44-47,141,195] & D2 agonist [165] & D2 agonist [136] & D2 agonist Low doses/inhibiting effect; \\
& & D1 agonist + D2 agonist & \\
D2 antagonist [74,153,165,214] & [32,39,43-47,56,58, \\
& $68,78,92,165]$ & \\
\end{tabular}



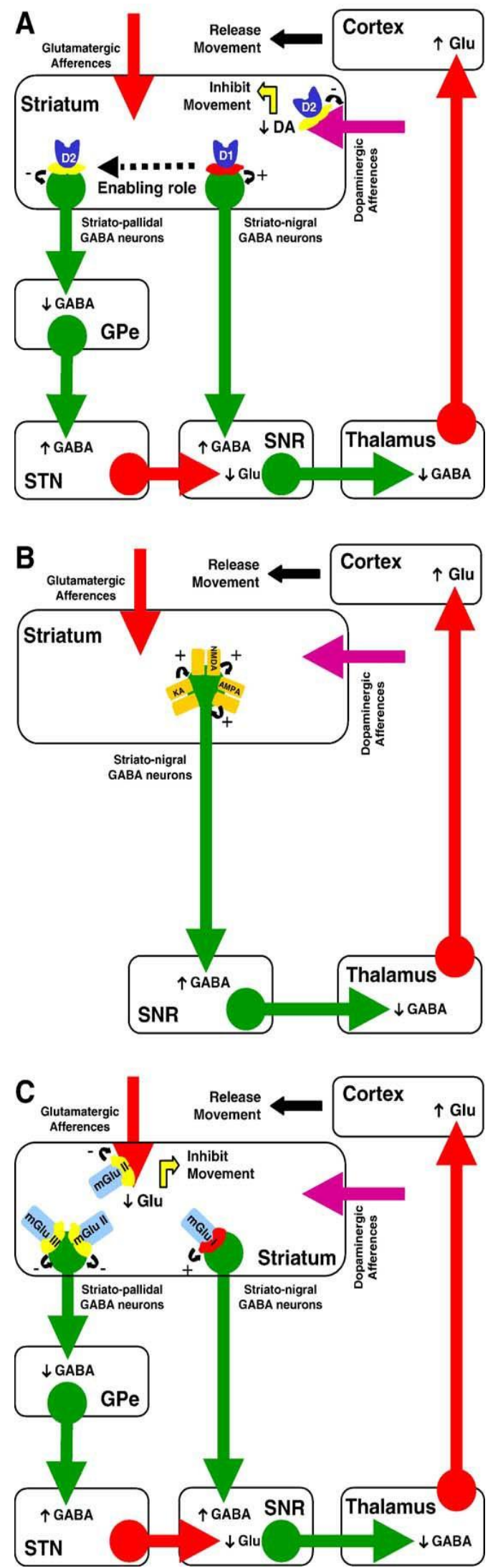

Fig. 3. (A) Illustration of the locomotor effects of striatal dopaminergic receptors. Activation of D1-like receptors increases locomotor activity, which is likely to be due to the predominant expression of D1-like receptors on the direct striato-nigral pathway. The physiology of D2-like receptors in the striatum appears more complex, probably due to the permissive, enabling, role of D1-like receptors on postsynaptic D2-like receptors activation, which mechanisms are still not elucidated. As a consequence, it is generally assumed that the effects observed after the administration of a D2-like receptor agonist alone reflect dopaminergic processes placed under the control of D2-like autoreceptors. Indeed, consistent with the decrease in striatal dopamine release produced by D2-like receptor activation, administration in the striatum of a D2-like receptor agonist is very generally found to produce a reduction of motor activity. However, it should be noted that other workers found an increase of locomotor activity following the injection in the striatum of a D2-like receptor agonist. Infusion of non selective D1-like and D2like receptor agonists or of a mixture of a selective D1-like receptor agonist and of a selective D2-like receptor agonist, a pharmacological condition thought to activate both striatal D1like receptors and presynaptic and postsynaptic D2-like receptors, has been consistently found to exert synergistic effects and to produce a much greater increase in locomotor activity, as compared to the injection of D1-like receptor agonists. Blockade of D1-like and/or D2-like receptors reduces motor activity (not illustrated). (B) Locomotor effects of striatal ionotropic glutamatergic (iGlu) receptors. Investigations on the locomotor effects iGlu receptors consistently found that activation of these receptors in the striatum had a facilitating action on locomotor activity that is likely to be mediated in a phasic manner through the direct pathway. Emphasizing the complexity of the glutamatergic function in the striatum, it should be noted that facilitating locomotor effects are also found following blockade of iGlu receptors, which effects are likely to be mediated through the indirect pathway in a tonic fashion (not shown). (C) Locomotor effects of striatal metabotropic glutamatergic (mGlu) receptors. Activation of group I mGlu receptors increases locomotor activity that may result from a phasic facilitating action on the direct striato-nigral pathway. Consistent with both anatomical and neurochemical findings of a presynaptic localization of group II mGlu receptors on glutamatergic terminals in the striatum, blockade of group II mGlu receptors in the NAcc, but not in the CP, increases locomotor activity. Further emphasizing the complexity of the glutamatergic function in the striatum, activation of group II or group III mGlu receptors induces an increase in locomotor activity likely to be due to be mediated through the indirect pathway. AMPA: AMPA ionotropic glutamatergic receptors; D1: D1-like dopaminergic receptors; D2: D2-ike dopaminergic receptors; DA: dopamine; Glu: glutamate; GPe: globus pallidus; KA: Kainate ionotropic glutamatergic receptors; mGlu I: group I metabotropic glutamatergic receptors; mGlu II: group II metabotropic glutamatergic receptors; mGlu III: group III metabotropic glutamatergic receptors; NMDA: NMDA ionotropic glutamatergic receptors; SNR: substantia nigra pars reticulata; STN: subthalamic nucleus. 


\section{BEHAVIORAL MOTOR INTERACTIONS BETWEEN IGLU RECEPTORS AND DOPAMINERGIC RECEPTORS (FIG. 4A)}

Existing literature on behavioral motor interactions between dopaminergic receptors and iGlu receptors is not extensive as studied by local injections in the striatum complex of "intact dopamine" animals and gave rise, in some cases, to controversial findings (Fig. 4A).

\section{Behavioral motor interactions between NMDA receptors and dopaminergic receptors.}

Early data reported no behavioral interaction in the nucleus accumbens between NMDA receptor activation and D1-like receptor activation by the D1-like receptor agonist SKF 38393, but provided evidence of a blocking effect of the D2-like receptor agonist LY 171555 on the increase in locomotor activity produced by NMDA receptor activation [228]. In contrast, recent investigations utilizing 5 -fold lower doses of NMDA (that led to no behavioral effect when given alone) and 4-fold lower doses of SKF 38393 and LY 171555 provided evidence of behavioral interactions between NMDA receptors and both D1-like receptors and D2-like receptors [47].

Given the dual effect of glutamate on striatal dopamine release, that is illustrated by the fact that low doses of NMDA inhibit dopamine release while high doses of NMDA increase it, the different doses of NMDA used between both studies may account for the discrepant data above. However, it should be emphasized that the potentiating and blocking effect of NMDA receptor activation, respectively, on the increase in locomotor activity produced by activation of D1-like receptors and co-activation of D1-like and D2-like receptors [47] is in good agreement with cellular, electrophysiological, and neurochemical investigations that have consistently shown, using in vivo, ex vivo or in vitro preparations from the caudate putamen, the nucleus accumbens, the cortex or the substantia nigra, a synergistic action between NMDA receptors and D1-like receptors $[34,35,61,73,132,184,185,241]$ and an antagonist action between NMDA receptors and D2-like receptors [106,132,241].

Altogether, these findings indicate that NMDA receptors interact both with D1-like receptors, located on striato-nigral medium spiny output neurons, and with D2-like presynaptic and postsynaptic receptors that are located, respectively, on dopaminergic and glutamatergic terminals and on striatopallidal spiny projection neurons in the striatum. In addition, these data further suggest that the glutamate neurotransmission mediated by NMDA receptors may interact with the dopaminergic neurotransmission mediated by D1-like receptors in a phasic excitatory fashion enabling a facilitatory control of striato-nigral neurons. They also suggest that the glutamatergic neurotransmission mediated by NMDA receptors may interact with the dopaminergic transmission mediated by D2-like postsynaptic receptors in a phasic fashion that would be devoted to an inhibitory control of these neurons. 
Table 5. Behavioral motor effects of striatal ionotropic glutamatergic receptors

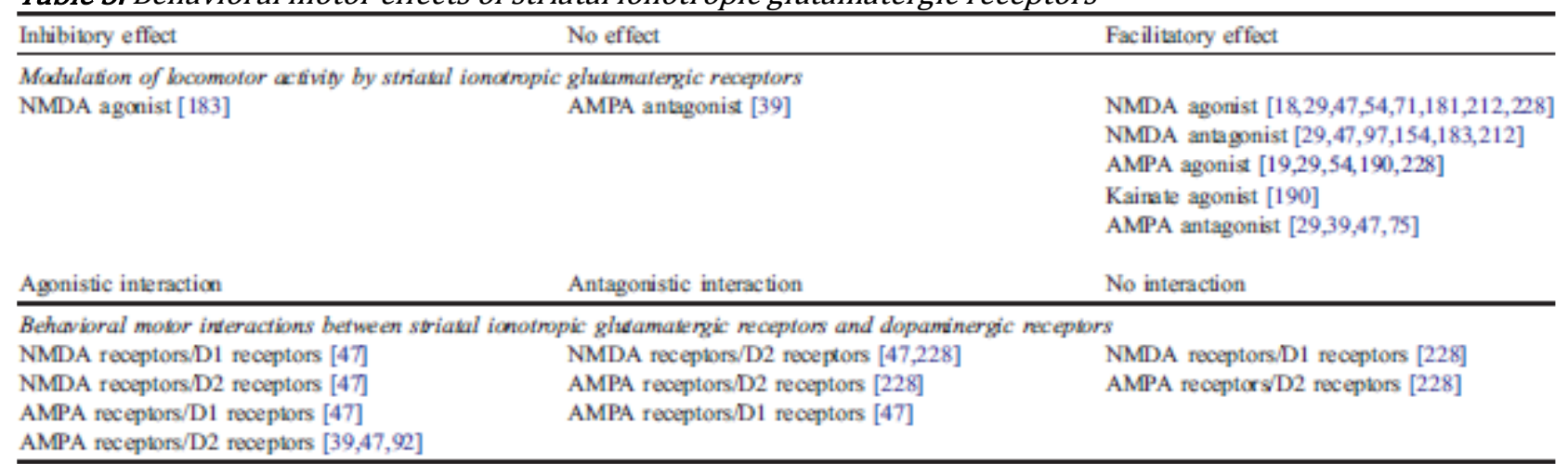

\section{Behavioral motor interactions between AMPA/kainate receptors and dopaminergic receptors.}

Early data reported no behavioral interaction in the nucleus accumbens between AMPA receptor activation and D1-like receptor activation by the D1-like receptor agonist SKF 38393, but provided evidence of a blocking effect of the D2-like receptor agonist LY 171555 on the increase in locomotor activity produced by AMPA receptor activation [228]. In contrast, recent investigations utilizing much lower doses of AMPA (25-fold less) and lower doses of SKF 38393 and LY 171555 (4-fold less) provided evidence of behavioral interactions between AMPA receptors and dopaminergic receptors. Infusion in the nucleus accumbens of AMPA or CNQX, an AMPA/kainate receptor antagonist, was found to reduce the increase in locomotor activity produced by the activation of D1-like receptors by SKF 38393 [47]. Administration of CNQX, but not of AMPA, further potentiated the decrease in basal locomotor activity induced by the D2-like receptor agonist LY 171555 [47] or the D2-like receptor agonist 7-OH-DPAT [39]. In addition, administration of AMPA and of CNQX, respectively, potentiated and reduced the locomotoractivating effects induced by co-infusion of SKF 38393 + LY 171555 [47,92].

Altogether these data indicate that AMPA/kainate receptors interact with D1-like and D2-like presynaptic and postsynaptic receptors. In addition, they further suggest that the glutamatergic neurotransmission mediated by AMPA/kainate receptors may interact with the dopaminergic transmission mediated by D1-like receptors in phasic manner that would be devoted to an inhibitory control of striato-nigral GABAergic output neurons. Glutamate-dopamine interactions mediated by AMPA/kainate and D2-like postsynaptic receptors, respectively, may involve phasic mechanisms of control allowing a facilitatory modulation of striato-pallidal neurons. 

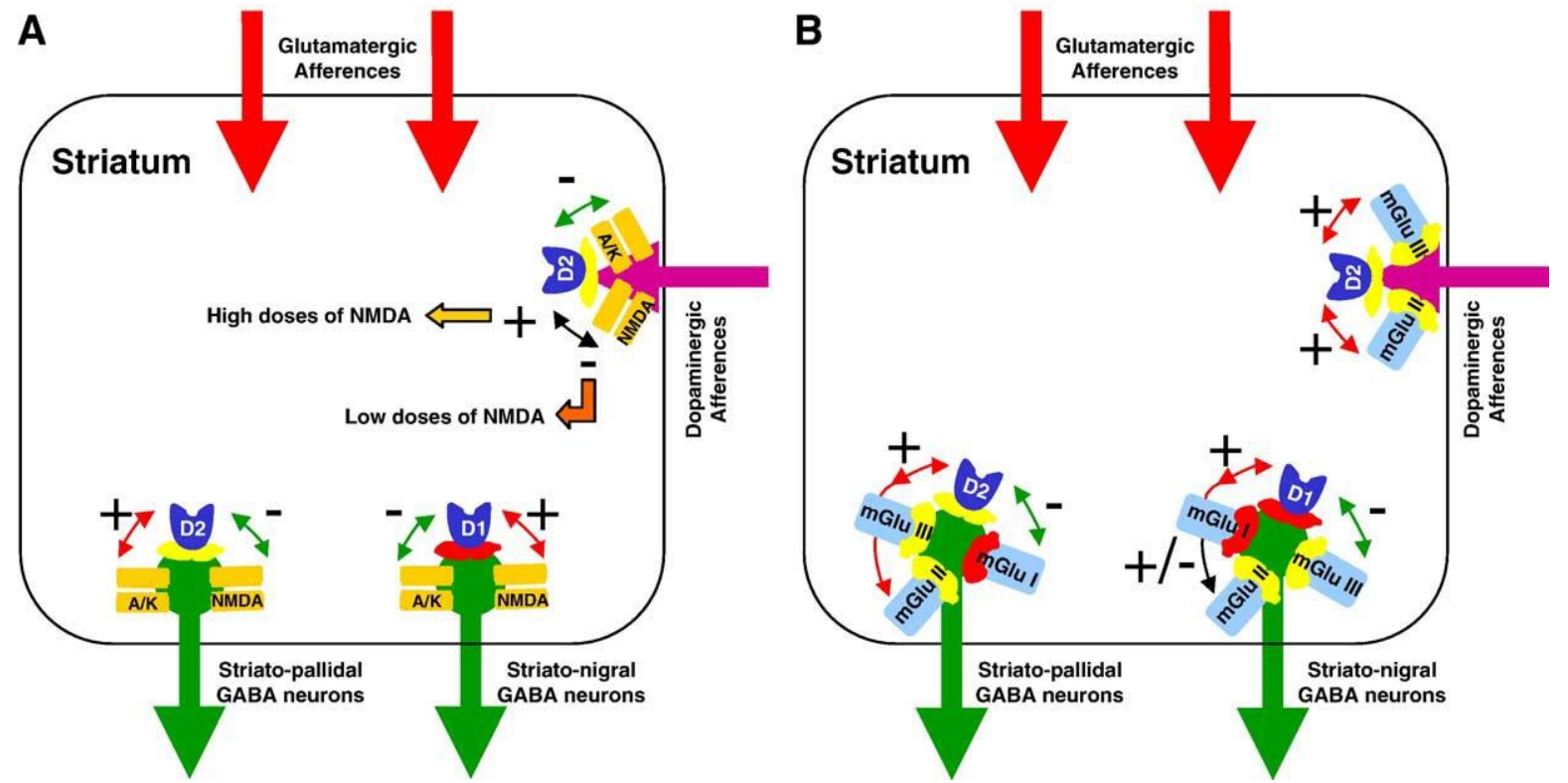

Fig. 4. Illustration of the interactions between dopaminergic receptors and both ionotropic glutamatergic (iGlu) receptors and metabotropic glutamatergic (mGlu) on locomotor activity. (A) NMDA receptors interact positively with D1-like receptors, leading to a facilitating action on locomotor activity mediated by D1-like receptor activation. In contrast, NMDA receptors interact negatively with D2-like postsynaptic receptors, leading to a reduction of the increase in locomotor activity induced by activation of these receptors. Consistent with neurochemical findings on glutamatergic control of striatal dopamine release, activation of NMDA receptors by low, physiological doses of NMDA potentiates the decrease in locomotor activity produced by activation of D2-like autoreceptors, whereas higher, possibly non-physiological doses of NMDA inhibits it. Constrating with the role of NMDA receptors, AMPA/kainate receptors interact negatively with D1-like receptors, leading to a reduction of the locomotor activity mediated by D1like receptor activation. It should be noted that blockade of AMPA/kainate receptors also inhibit the increase in locomotor activity induced D1-like receptor activation. Stimulation of AMPA/kainate receptors potentiate the locomotor activity produced by D2-like postsynaptic receptors activation but inhibit the decrease in locomotor activity produced by activation of D2-like autoreceptors; conversely, blockade of AMPA/kainate receptors potentiate the decrease in locomotor activity induced by D2-like autoreceptor activation (not shown). (B) Group I metabotropic glutamatergic (mGlu) receptors interact positively with D1-like receptors, leading to an increase of locomotor activity produced by D1-like receptor activation. In contrast, group I mGlu receptors interact negatively with D2-like postsynaptic receptors, leading to a reduction of the increase in locomotor activity induced by activation of these receptors. Some studies showed that activation of group II mGlu receptors potentiates the locomotor activity mediated by D1-like receptors, while others found that activation of group II mGlu receptors oppose the D1-like receptor locomotor response. In addition, group II mGlu receptors favor the locomotor response produced by D2-like receptors, leading to a potentiation of the increase of locomotor activity induced by D2-like postsynaptic receptor activation and of the decrease of locomotor activity produced by activation of D2-like autoreceptors activation. Group III mGlu interact negatively with D1-like receptors, leading to a decrease of the locomotor activity produced by activation of D1-like receptors, and positively with D2-like receptors, to leading to a potentiation of the increase of locomotor activity induced by D2-like postsynaptic receptor activation and of the decrease of locomotor activity produced by activation of D2-like autoreceptors activation. A/K: AMPA/kainate ionotropic glutamatergic receptors; D1: D1-like dopaminergic receptors; D2: D2-like dopaminergic receptors; mGlu I: group I metabotropic glutamatergic receptors; mGlu II: group II metabotropic glutamatergic receptors; mGlu III: group III metabotropic glutamatergic receptors; NMDA: NMDA ionotropic glutamatergic receptors. 


\title{
BEHAVIORAL MOTOR EFFECTS OF STRIATAL MGLU RECEPTORS (TABLE 6)
}

\author{
INTRINSIC BEHAVIORAL MOTOR RESPONSES PRODUCED BY MGLU RECEPTORS (FIG. \\ 3C)
}

Studies on the behavioral motor effects of mGlu receptors within the striatum started with behavioral investigations from Schoepp's group $[179,180]$ that showed that an acute unilateral injection of the non-selective group I/group II mGlu receptor agonist ACPD into the caudateputamen produced rotation contralateral to the injection side (Table 6). Similar results showing behavioral activation following bilateral injection of ACPD into the caudate- putamen or the nucleus accumbens were obtained afterwards $[9,101]$. Then, further studies were conducted, using group selective mGlu receptor agonists and antagonists, on the role of mGlu receptors in the control of locomotor activity.

\section{Behavioral motor effects of group I mGlu receptors.}

Studies on the locomotor effects of the selective group I mGlu receptors consistently found that the selective group I mGlu receptor agonist DHPG had a facilitating action on locomotor activity, when infused locally in the caudate-putamen [128,220] or the nucleus accumbens ([44, 196,198] but [26]). This effect was blocked by co-treatment with group I mGlu receptor antagonists [41,196,220], but not group II or group III mGlu receptor antagonists [44]. All of the group I mGlu receptor antagonists used, either CPC-COEt at $10 \mathrm{nmol}$. (i.e., $2.5 \mu \mathrm{g}$ ) [196], PHCCC at $10 \mathrm{nmol}$ (i.e., $3 \mu \mathrm{g}$ ) [220] or S-4-CPG at $10 \mathrm{nmol}$ (i.e., $2 \mu \mathrm{g}$ ) [44], as well as AIDA at $9 \mathrm{nmol}$ (i.e., $2 \mu \mathrm{g})$ [102], had no effect by themselves on locomotor activity when administered alone in the nucleus accumbens or the caudate-putamen; this agrees with anatomical data that showed that group I mGlu receptors are not located on glutamatergic terminals in the striatum, and further suggests that group I mGlu receptors-mediated glutamatergic transmission exerts a phasic facilitating control on striatal activity. In addition, data have shown that the effect of DHPG on locomotor activity was not altered by co-treatment with the mGlu5 receptor antagonist MPEP, indicating that DHPG may act preferentially at the mGlu1 receptor rather than at the mGlu5 receptor; in contrast with the motor-activating properties of DHPG, infusion in the nucleus accumbens of the mGlu5 selective agonist CHPG did not elicit an increase in locomotor activity [198].

It is not clear whether the locomotor-activating effects of DHPG injected directly in the caudateputamen are independent of iGlu receptors. The NMDA receptor antagonist CPP did not alter the DHPG-induced behavioral activation [128]. However, AMPA receptor blockade has been reported to have no effect [128] or to inhibit [198] locomotor activity produced by local administration of DHPG.

\section{Behavioral motor effects of group II mGlu receptors.}

Investigations on the role and function of group II mGlu receptors gave rise to more controversial data. Depending on the ligands used and/or of the brain area explored, activation of group II mGlu receptors had no effect, or resulted in an increase or a decrease in locomotor activity. Infusion in the nucleus accumbens of the group II mGlu receptor agonists L-CCG-I [26] and DCG-IV [196] increased locomotor activity. The motor-activating properties of L-CCG-I and DCG-IV were, respectively, attenuated, but not blocked, by co-treatment with the group II/III 
mGlu receptor antagonist MCCG at $50 \mathrm{nmol}$ (i.e., $8.7 \mu \mathrm{g}$ ) [26] or the group II/III mGlu receptor antagonist MPPG at $10 \mathrm{nmol}$ (i.e., $2.5 \mu \mathrm{g}$ ) [196], which had no effect by themselves on locomotor activity when administered alone. One potential limitation to this observation is the reported action of DCG-IV on NMDA receptors [28]. However, co-administration of the NMDA receptor antagonist CPP did not alter the increase in locomotor activity produced by DCG-IV [196], indicating that the locomotor-activating properties of DCG-IV are mediated through mGlu receptors. Alternatively, consistent with anatomical and neurochemical data of a presynaptic localization, as well as a postsynaptic localization, of group II mGlu receptors on glutamatergic terminals in the striatum, data have reported that infusion in the nucleus accumbens of the group II mGlu receptor antagonist LY 341495 induced a dose-dependent increase in motor activity, effect that was blocked by co-treatment with the group II mGlu receptor agonist APDC that had no behavioral effect by itself [45].

In contrast with its effect in the nucleus accumbens, administration in the caudate- putamen of L-CCG-I showed no effect [111] and DCG-IV led to a decrease in locomotor activity that was partly reversed by co-treatment with $10 \mathrm{nmol}$ (i.e., $2.8 \mu \mathrm{g}$ ) MSOPPE, a group II mGlu receptor antagonist that produced a slight increase in locomotor activity when given alone [127].

Table 6. Behavioral motor effects of striatal metabotropic glutamatergic receptors

\begin{tabular}{|c|c|c|}
\hline Inhibitory effect & No effect & Facilitatory effect \\
\hline \multicolumn{3}{|c|}{ Modulation of bicomotor activing by striabl metabotropic glabumatengic receptors } \\
\hline \multirow[t]{7}{*}{ Group II agonist [127] } & Group I agonist [26] & Group LI agonis $[9,101,179,180]$ \\
\hline & Group I antagonist $[44,102,196,220]$ & Group I agonis $[44,128,196,198,220]$ \\
\hline & mGluRS agonist [198] & Group II agonist $[26,196]$ \\
\hline & Group II agonist $[45,111]$ & Group II antagonist $[45,127]$ \\
\hline & Group II antagonist $[26,196]$ & Group III agonist $[46,196]$ \\
\hline & Group III agonist $[111,129]$ & \\
\hline & Group III antagonist $[46,129,196]$ & \\
\hline Agonistic interaction & Antagonistic interaction & No interaction \\
\hline \multicolumn{3}{|c|}{ Behavioral mobor interactions between strialal metabotrpic glubamatergic receptors and dopaminergic neceptars } \\
\hline Group I receptors/D1 receptors [44; unpublished data] & Group I receptors/D2 receptors (unpublished data) & Group I receptors/D2 receptors [44] \\
\hline Group II receptors/D1 receptors $[26,45]$ & Group II receptors/D1 receptors [111] & Group II receptors D2 receptors [111] \\
\hline Group II receptors $D 2$ receptors $[26,45]$ & Group III receptors'D1 receptors [46] & \\
\hline \multicolumn{3}{|l|}{ Group III receptors:D2 receptors [46] } \\
\hline
\end{tabular}

\section{Behavioral motor effects of group III mGlu receptors.}

Studies on the functional role of group III mGlu receptors found that infusion of the group III mGlu receptor agonist L-AP4 in the nucleus accumbens $[46,196]$, but not in the caudateputamen $[111,129]$, led to an increase in locomotor activity that was blocked by cotreatment with the group III mGlu receptor antagonist MPPG [43]. Infusion of MPPG in the nucleus accumbens $[46,196]$ or the caudate-putamen [129] was found to be ineffective by itself at changing locomotor activity.

\section{BEHAVIORAL MOTOR INTERACTIONS BETWEEN MGLU RECEPTORS AND DOPAMINERGIC RECEPTORS (FIG. 4B)}

A few studies have investigated behavioral interactions between mGlu receptors and dopaminergic receptors within the striatum complex of Fintact_ animals by using locally applied drugs. 


\section{Behavioral interactions between group I mGlu receptors and dopaminergic receptors.}

Infusion in the nucleus accumbens of the group I mGlu receptor agonist DHPG, at a dose that produced behavioral activation by itself, has been reported to potentiate the increase in locomotor activity produced by the D1-like receptor agonist SKF 38393 (unpublished data). Administration of DHPG further blocked the decrease in locomotor activity produced by the D2like receptor agonist LY 171555 alone (unpublished data), and reduced the locomotor-activating properties of co-administration of SKF 38393 + LY 171555 (unpublished data). Infusion in the nucleus accumbens of the group I mGlu receptor antagonist S-4-CPG, which had no behavioral effect when injected alone, was found to abolish the increase in locomotor activity produced by the D1-like receptor agonist SKF 38393 [44]. In contrast, S-4-CPG showed no effect [44] on either the decrease in basal locomotor activity induced by the D2-like receptor agonist LY 171555 or the increase in locomotor activity induced by co-administration of SKF $38393+$ LY 171555.

Altogether, these data indicate that the glutamate neurotransmission mediated by group I mGlu receptors may interact with the dopaminergic neurotransmission mediated by D1-like receptors in a phasic excitatory fashion enabling a facilitatory control of striato-nigral neurons, while it may interact in a phasic inhibitory fashion with D2-like postsynaptic receptors.

\section{Behavioral interactions of group II mGlu receptors with dopaminergic receptors.}

Administration of the group II mGlu receptor agonist L-CCG-I in the caudate putamen has been demonstrated to potentiate the decrease in locomotor activity in rats pretreated with the D1like receptor antagonist SCH 23390, but not by the non-selective D1-like/D2-like receptor antagonist haloperidol, showing that group II mGlu receptor-mediated glutamatergic neurotransmission may oppose D1-like-mediated dopaminergic neurotransmission on striatonigral neurons [111]. In contrast, other workers have found that the locomotor stimulant effect induced by application of L-CCG-I in the nucleus accumbens was abolished by selective D1-like or D2-like receptor antagonists [26].

Data from another group have shown that infusion in the nucleus accumbens of the group II mGlu receptor agonist APDC, which had no effect on basal locomotor activity when injected alone, potentiated the locomotor-activating properties of the D1-like receptor agonist SKF 38393, but showed no effect on the locomotor responses produced by the D2-like receptor agonist LY 171555 or co-infusion of SKF 38393 + LY 171555 [45]. In contrast, infusion of the group II mGlu receptor antagonist LY 341495, which increased basal locomotor activity by itself when given alone, blocked the locomotor responses induced by the D2-like receptor agonist LY 171555 or co-infusion of SKF $38393+$ LY 171555, but did not change that induced by the D1like receptor agonist SKF 38393. Pharmacologically, the effects of the group II mGlu receptor antagonist LY 341495 were blocked by the group II mGlu receptor agonist APDC and conversely. Altogether these findings indicate that activation of group II mGlu receptors would have an agonist action on D1-like receptor activation and that blockade of group II mGlu receptors would have an antagonistic action on presynaptic and postsynaptic D2-like receptors. They further suggest that the glutamate neurotransmission mediated by group II mGlu receptors may interact with the dopaminergic neurotransmission mediated by D1-like receptors in a phasic facilitatory control of striato-nigral output neurons, while it may exert a tonic facilitatory control of striatopallidal output neurons mediated by D2 postsynaptic receptors. 


\section{Behavioral interactions of group III mGlu receptors with dopaminergic receptors.}

Administration in the nucleus accumbens of the group III mGlu receptor agonist L-AP4 was found to prevent the locomotor activation produced by the D1-like receptor agonist SKF 38393 and to potentiate the locomotor responses induced by either the D2-like receptor agonist LY 171555 or co-infusion of SKF 38393 + LY 171555 [46]. Alternatively, although the group III mGlu receptor antagonist MPPG had no effect on the increase in locomotor activity induced by the D1-like receptor agonist SKF 38393, it totally blocked the decrease in motor response produced by the D2-like receptor agonist LY 171555 and further potentiated, as the group III mGlu receptor agonist L-AP4 did, the locomotor-activating effects of co-infusion of the D1-likeand D2-like receptor agonists SKF 38393 and LY 171555 [unpublished data].

These findings demonstrated that stimulation of group III mGlu receptors opposes the behavioral responses induced by D1-like receptor activation, but favors those induced by activation of D2-like receptors, and further indicated that group I and group III mGlu receptors oppose each other in the control of dopaminergic neurotransmission in the nucleus accumbens. In addition, these data further suggested that the glutamatergic transmission mediated by group III mGlu receptors may interact with the dopaminergic neurotransmission mediated by D1-like receptor in phasic fashion enabling an inhibitory control of striato-nigral output neurons, while it may interact with D2-like postsynaptic receptors in a tonic/phasic fashion that would be only devoted to a facilitatory, but not to an inhibitory, control of striato-pallidal output neurons. Such an inhibitory control of striato-pallidal neurons may involve glutamatergic terminals arising from different brain areas that project to the striatum and/or different subtypes of group III mGlu receptors.

\section{Conclusion}

In contrast with previous data that focused mainly on iGlu receptors, it now appears that glutamatergic modulation of dopamine release in the striatum complex may be both facilitatory and inhibitory, depending on the type of receptors and subtypes of receptors involved. While there is a considerable amount of evidence that glutamatergic control of dopamine release by iGlu receptors may be mainly facilitatory and phasic in nature, evidence has been reported that, depending on the degree of receptor activation, both inhibitory and excitatory effects can be elicited. Alternatively, evidence has been presented that glutamatergic modulation of dopamine release by mGlu receptors may be mediated by group II and/or group III mGlu receptors, but not by group I mGlu receptors, although the role of mGlu receptors subtypes remains to be elucidated. Reciprocally, dopamine modulates glutamate release in the striatum through D2-like receptors, and there is a body of evidence that dopaminergic control of striatal glutamate release is mainly inhibitory and phasic in nature.

Although it was previously believed that dopaminergic and glutamatergic transmission in the striatum work in a functional antagonism or agonism (which led to a matter of debate and controversy) to modulate cognitive and motor functions, the data summarized in the present study do not support this view. Indeed, evidence has been presented that the two transmitters do not uniformly interact to modulate each others' release and postsynaptic modulation of striatal output neurons. As previously suggested [144], recent behavioral studies provide strong 
evidence that depending on the receptor subtypes involved (and the experimental conditions employed), interactions between dopaminergic and glutamatergic transmission vary as a multiple and complex combination of tonic, phasic, facilitatory, and inhibitory properties. 


\section{References}

[1] J.H. Abraini, C. Tomei, J.-C. Rostain, Role of dopamine receptors in the occurrence of the behavioral motor disturbances in rats exposed to high pressure, Pharmacol. Biochem. Behav. 39 (1991) 773 - 779.

[2] J.H. Abraini, T. Fechtali, J.-C. Rostain, Pressure reversed extracellular striatal dopamine decrease produced by D1 receptor agonist SKF 38393, and D2 receptor agonist LY 171555, but failed to change the effect of the activation of both D1 and D2 receptors, Neuroscience 50 (1992) 395 - 402.

[3] R.L. Albin, R.L. Makowiec, Z.R. Hollingsworth, L.S. Dure IV, J.B. Penney, A.B. Young, Excitatory amino acid binding sites in the basal ganglia of the rat: a quantitative autoradiographic study, Neuro-cience 46 (1992) $35-48$.

[4] A.A. Alcantara, V. Chen, B.E. Herring, J.M. Mendenhall, M.L. Berlanga, Localization of dopamine D2 receptors on cholinergic interneurons of the dorsal striatum and nucleus accumbens of the rat, Brain Res. $986(2003) 22-29$.

[5] G.E. Alexander, M.D. Crutcher, Functional architecture of basal ganglia circuits: neural substrates of parallel processing, Trends Neurosci. 13 (1990) $266-271$.

[6] T. Antonelli, B.M. Govoni, C. Bianchi, L. Beani, Glutamate regulation of dopamine release in guinea pig striatal slices, Neurochem Int. 30 (1997) 203 - 209.

[7] T. Aosaki, K. Kiuchi, Y. Kawaguchi, Dopamine D1-like receptor activation excites rat striatal large aspiny neurons in vitro, J. Neurosci. 18 (1998) 5180 - 5190.

[8] I. Arai, T. Shimazoe, S. Shibata, H. Inoue, A. Yoshimatsu, S. Watanabe, Enhancement of dopamine release from the striatum through metabotropic glutamate receptor activation in methamphetamine sensitized rats, Brain Res. 729 (1996) 227 - 280.

[9] S. Attarian, M. Amalric, Microinfusion of the metabotropic glutamate receptor agonist 1S,3R-1aminocyclopentane-1,3-dicarboxylic acid into the nucleus accumbens induces dopamine-dependent locomotor activation in the rat, Eur. J. Neurosci. 9 (1997) 809 - 816.

[10] J.M. Barnes, N.M. Barnes, B. Costall, R.J. Naylor, The actions of (-)N-n-propylnorapomorphine and selective dopamine D1 and D2 receptor agonists to modify the release of [3H]dopamine from the rat nucleus accumbens, Neuropharmacology 29 (1990) 327 - 336.

[11] G. Battaglia, V. Bruno, A. Pisani, D. Centonze, M.V. Catania, P. Calabresi, F. Nicoletti, Selective blockade of type-1 metabotropic glutamate receptors induces neuroprotection by enhancing gabaergic transmission, Mol. Cell. Neurosci. 17 (2001) 1071 - 1083

[12] M.I. Bell, P.J. Richardson, K. Lee, Functional and molecular characterization of metabotropic glutamate receptors expressed in rat striatal cholinergic interneurones, J. Neurochem. 81 (2002) 142 - 149.

[13] M.A. Berger, M.C. Defagot, M.J. Villar, M.C. Antonelli, D4 dopamine and metabotropic glutamate receptors in cerebral cortex and striatum in rat brain, Neurochem. Res. 26 (2001) 345 - 352.

[14] C. Bergson, L. Mrzljiak, J.F. Smiley, M. Pappy, R. Levenson, P.S. Goldman-Rakic, Regional, cellular, and subcellular variations in the distribution of D1 and D5 dopamine receptors in primate brain, J. Neurosci. 15 (1995) $7821-7836$.

[15] V. Bernard, A. Gardiol, B. Faucheux, B. Bloch, Y. Agid, E.C. Hirsch, Expression of glutamate receptors in the human and rat basal ganglia: effect of the dopaminergic denervation on AMPA receptor gene 
expression in the striatopallidal complex in Parkinson's disease and rat with 6-OHDA lesion, J. Comp. Neurol. 368 (1996) 553 - 568.

[16] M.B. Bogdanov, R.J. Wurtman, Possible involvement of nitric oxide in NMDA-induced glutamate release in the rat striatum: an in vivo microdialysis study, Neurosci. Lett. 221 (1997) 197 - 201.

[17] J.P. Bolam, J.J. Hanley, P.A. Booth, M.D. Bevan, Synaptic organisation of the basal ganglia, J. Anat. 196 (2000) $527-542$.

[18] R.C. Boldry, N.J. Uretsky, The importance of dopaminergic neurotransmission in the hypermotility response produced by the administration of $\mathrm{N}$-methyl-d-aspartic acid into the nucleus accumbens, Neuropharmacology 27 (1988) 569 - 577.

[19] R.C. Boldry, D.L. Willins, L.J. Wallace, N.J. Uretsky, The role of endogenous dopamine in the hypermotility response to intra-accumbens AMPA, Brain Res. 559 (1991) 100 - 108.

[20] M.L. Bouthenet, E. Souil, M.P. Martres, P. Sokoloff, B. Giros, J.C. Schwartz, Localization of dopamine D3 receptor mRNA in the rat brain using in situ hybridization histochemistry: comparison with dopamine D2 receptor mRNA, Brain Res. 564 (1991) 203 - 219.

[21] J.J. Bouyer, D.H. Park, T.H. Joh, V.M. Pickel, Chemical and structural analysis of the relation between cortical inputs and tyrosine hydroxylase-containing terminals in rat neostriatum, Brain Res. 302 (1984) $267-275$.

[22] J.F. Bowyer, A.C. Scallet, R. Holson, G.W. Lipe, W. Slikker Jr., S.F. Ali, Interactions of MK-801 with glutamate-, glutamine- and methamphetamine-evoked release of [3H] dopamine from striatal slices, J. Pharmacol. Exp. Ther. 257 (1991) 262 - 270.

[23] J.F. Bowyer, G.D. Newport, G.W. Lipe, L.T. Frame, A further evaluation of the effects of K+ depolarization on glutamate-evoked $[3 \mathrm{H}]$ dopamine release from striatal slices, J. Pharmacol. Exp. Ther. 261 (1992) $72-80$.

[24] S.R. Bradley, D.G. Standaert, A.I. Levey, P.J. Conn, Distribution of group III mGluRs in rat basal ganglia with subtype-specific antibodies, Ann. N. Y. Acad. Sci. 868 (1999) 531 - 534.

[25] S.R. Bradley, D.G. Standaert, K.J. Rhodes, H.D. Rees, C.M. Testa,

A.I. Levey, P.J. Conn, Immunohistochemical localization of subtype 4a metabotropic glutamate receptors in the rat and mouse basal ganglia, J. Comp. Neurol. 407 (1999) 33 - 46.

[26] N. Breysse, C. Risterucci, M. Amalric, D1 and D2 dopamine receptors contribute to the locomotor response induced by Group II mGluRs activation in the rat nucleus accumbens, Pharmacol. Biochem. Behav. 73 (2002) 347 - 357.

[27] R.K. Bruton, J. Ge, N.M. Barnes, Group I mGlu receptor modulation of dopamine release in the rat striatum in vivo, Eur. J. Pharmacol. 369 (1999) 175 - 181.

[28] A. Buisson, S.P. Yu, D.W. Choi, DCG-IV selectively attenuates rapidly triggered NMDA-induced neurotoxicity in cortical neurons, Eur. J. Neurosci. 8 (1996) 138 - 143.

[29] L.H. Burns, B.J. Everitt, A.E. Kelley, T.W. Robbins, Glutamate-dopamine interactions in the ventral striatum: role in locomotor activity and responding with conditioned reinforcement, Psychopharmacology (Berlin) 115 (1994) 516 - 528.

[30] G. Bustos, J. Abarca, M.I. Forray, K. Gysling, C.W. Bradberry, R.H. Roth, Regulation of excitatory amino acid release by N-methyl-D-aspartate receptors in rat striatum: in vivo microdialysis studies, Brain Res. 585 (1992) $105-115$. 
[31] N.S. Cai, B. Kiss, S.L. Erdo, Heterogeneity of N-methyl-d-aspartate receptors regulating the release of dopamine and acetylcholine from striatal slices, J. Neurochem. 57 (1991) 2148 - 2151.

[32] J.J. Canales, S.D. Iversen, Dynamic dopamine receptor interactions in the core and shell of nucleus accumbens differentially coordinate the expression of unconditioned motor behaviors, Synapse 36 (2000) $297-306$.

[33] D.P. Carrozza, T.N. Ferraro, G.T. Golden, P.F. Reyes, T.A. Hare, In vivo modulation of excitatory amino acid receptors: microdialysis studies on $\mathrm{N}$-methyl-d-aspartate-evoked striatal dopamine release and effects of antagonists, Brain Res. 574 (1992) 42 - 48.

[34] C. Cepeda, M.S. Levine, Dopamine and N-methyl-d-aspartate receptor interactions in the neostriatum, Dev. Neurosci. 20 (1998) 1 - 18.

[35] C. Cepeda, C.S. Colwell, J.N. Itri, S.H. Chandler, M.S. Levine, Dopaminergic modulation of NMDAinduced whole cell currents in neostriatal neurons in slices: contribution of calcium conductances, J. Neurophysiol. 79 (1998) 82 - 94.

[36] C. Cepeda, R.S. Hurst, K.L. Altemus, J. Flores-Hernandez, C.R. Calvert, E.S. Jokel, D.K. Grandy, M.J. Low, M. Rubinstein, M.A. Ariano, M.S. Levine, Facilitated glutamatergic transmission in the striatum of D2 dopamine receptor-deficient mice, J. Neurophysiol. 85 (2001) 659 - 670.

[37] Q. Chen, C.L. Veenman, A. Reiner, Cellular expression of ionotropic glutamate receptor subunits on specific striatal neuron types and its implication for striatal vulnerability in glutamate receptor-mediated excitotoxicity, Neuroscience 73 (1996) 715 - 731.

[38] A. Cheramy, J.M. Desce, G. Godeheu, J. Glowinski, Presynaptic control of dopamine synthesis and release by excitatory amino acids in rat striatal synaptosomes, Neurochem. Int. 25 (1994) 145 - 154.

[39] K.H. Choi, B. Zarandi, K.G. Todd, A.M. Biondo, A.J. Greenshaw, Effects of AMPA/kainate receptor blockade on responses to dopamine receptor agonists in the core and shell of the rat nucleus accumbens, Psychopharmacology (Berlin) 150 (2000) 102 - 111.

[40] D.W. Clow, K. Jhamandas, Characterization of L-glutamate action on the release of endogenous dopamine from the rat caudate- putamen, J. Pharmacol. Exp. Ther. 248 (1989) 722 - 728.

[41] A. Cozzi, S. Attuci, F. Peruginelli, M. Marinozzi, R. Luneia, R. Pellicciari, F. Moroni, Type 2 metabotropic glutamate (mGlu) receptors tonically inhibit transmitter release in rat caudate nucleus: in vivo studies with (2S,1VS,2VS,3VR)-2-(2V-carboxy-3V-phenyl-cyclopropyl)glycine, a new potent and selective antagonist, Eur. J. Neurosci. 9 (1997) 1350 - 1355.

[42] J.M. Crowder, H.F. Bradford, Inhibitory effects of noradrenaline and dopamine on calcium influx and neurotransmitter glutamate release in mammalian brain slices, Eur. J. Pharmacol. 143 (1987) 343 - 352.

[43] A. Dalia, N.J. Uretsky, L.J. Wallace, Dopaminergic agonists administered into the nucleus accumbens: effects on extracellular glutamate and on locomotor activity, Brain Res. 788 (1998) 111 - 117.

[44] H.N. David, J.H. Abraini, The group I metabotropic glutamate receptor antagonist S-4-CPG modulates the locomotor response produced by the activation of D1-like, but not D2-like, dopamine receptors in the rat nucleus accumbens, Eur. J. Neurosci. 13 (2001) 2157 - 2164.

[45] H.N. David, J.H. Abraini, Differential modulation of the D1-like- and D2-like dopamine receptorinduced locomotor responses by group II metabotropic glutamate receptors in the rat nucleus accumbens, Neuropharmacology 41 (2001) $454-463$. 
[46] H.N. David, J.H. Abraini, Group III metabotropic glutamate receptors and D1-like and D2-like dopamine receptors interact in the rat nucleus accumbens to influence locomotor activity, Eur. J. Neurosci. 15 (2002) $869-875$.

[47] H.N. David, K. Sissaoui, J.H. Abraini, Modulation of the locomotor responses induced by D(1)-like and $\mathrm{D}$ (2)-like dopamine receptor agonists and d-amphetamine by NMDA and non-NMDA glutamate receptor agonists and antagonists in the core of the rat nucleus accumbens, Neuropharmacology 46 (2004) 179 191.

[48] J.M. Desce, G. Godeheu, T. Galli, F. Artaud, A. Cheramy, J. Glowinski, L-glutamate-evoked release of dopamine from synaptosomes of the rat striatum: involvement of AMPA and N-methyl-D-aspartate receptors, Neuroscience 47 (1992) 333 - 339.

[49] P. Devoto, M. Collu, A.L. Muntoni, M. Pistis, G. Serra, G.L. Gessa, M. Diana, Biochemical and electrophysiological effects of 7-OH-DPAT on the mesolimbic dopaminergic system, Synapse 20 (1995) $153-155$.

[50] J. Diaz, D. Levesque, N. Griffon, C.H. Lammers, M.P. Martres, P. Sokoloff, J.C. Schwartz, Opposing roles for dopamine D2 and D3 receptors on neurotensin mRNA expression in nucleus accumbens, Eur. J. Neurosci. 6 (1994) 1384 - 1387.

[51] J. Diaz, D. Levesque, C.H. Lammers, N. Griffon, M.P. Martres, J.C. Schwartz, P. Sokoloff, Phenotypical characterization of neurons expressing the dopamine D3 receptor in the rat brain, Neuroscience 65 (1995) $731-745$.

[52] R. Dingledine, K. Borges, D. Bowie, S.F. Traynelis, The glutamate receptor ion channels, Pharmacol. Rev. 51 (1999) 7 - 61.

[53] R. Dohovics, R. Janaky, V. Varga, A. Hermann, P. Saransaari, S.S. Oja, Regulation of glutamatergic neurotransmission in the striatum by presynaptic adenylyl cyclase-dependent processes, Neurochem. Int. $42(2003) 1-7$.

[54] B.A. Donzanti, N.J. Uretsky, Effects of excitatory amino acids on locomotor activity after bilateral microinjection into the rat nucleus accumbens: possible dependence on dopaminergic mechanisms, Neuropharmacology 22 (1983) 971 - 981.

[55] B.A. Donzanti, J.F. Hite, B.K. Yamamoto, Extracellular glutamate levels increase with age in the lateral striatum: potential involvement of presynaptic D-2 receptors, Synapse 13 (1993) 376 - 382.

[56] J.K. Dreher, D.M. Jackson, Role of D1 and D2 dopamine receptors in mediating locomotor activity elicited from the nucleus accumbens of rats, Brain Res. 487 (1989) 267 - 277.

[57] R.M. Eglen, A. Choppin, N. Watson, Therapeutic opportunities from muscarinic receptor research. Trends Pharmacol. Sci. 22 (2001) 409 - 414.

[58] W.D. Essman, P. McGonigle, I. Lucki, Anatomical differentiation within the nucleus accumbens of the locomotor stimulatory actions of selective dopamine agonists and d-amphetamine, Psychopharmacology (Berlin) 112 (1993) 233 - 241.

[59] I. Exposito, B. Sanz, A. Porras, F. Mora, Effects of apomorphine and L-methionine sulphoximine on the release of excitatory amino acid neurotransmitters and glutamine in the striatum of the conscious rat, Eur. J. Neurosci. 6 (1994) 287 - 291.

[60] H. Fink, R. Morgenstern, T. Ott, CCK-8 modulates D2 receptor agonist-induced hypermotility in the nucleus accumbens, Brain Res. Bull. 26 (1991) $437-440$. 
[61] J. Flores-Hernandez, C. Cepeda, E. Hernandez-Echeagaray, C.R. Calvert, E.S. Jokel, A.A. Fienberg, P. Greengard, M.S. Levine, Dopamine enhancement of NMDA currents in dissociated medium sized striatal neurons: role of D1 receptors and DARPP-32, J. Neurophysiol. 88 (2002) 3010 - 3020.

[62] E.D. French, C. Pilapil, R. Quirion, Phencyclidine binding sites in the nucleus accumbens and phencyclidine-induced hyperactivity are decreased following lesions of the mesolimbic dopamine system, Eur. J. Pharmacol. 116 (1985) 1 - 9.

[63] F. Fujiyama, E. Kuramoto, K. Okamoto, H. Hioki, T. Furuta, L. Zhou, S. Nomura, T. Kaneko, Presynaptic localization of an AMPA-type glutamate receptor in corticostriatal and thalamostriatal axon terminals, Eur. J. Neurosci. 20 (2004) 3322 - 3330.

[64] K. Fuxe, L. Agnati, Two principal modes of electrochemical communication in the brain: volume versus wiring transmission, in: K. Fuxe, L. Agnati (Eds.), Advances in Neuroscience, Volume transmission in the brain, Novel mechanisms for neural transmission, vol. 1, Raven Press, New York, 1991, pp. 1 - 9.

[65] R.R. Gainetdinov, T.D. Sotnikova, T.V. Grekhova, K.S. Rayevsky, In vivo evidence for preferential role of dopamine D3 receptor in the presynaptic regulation of dopamine release but not synthesis, Eur. J. Pharmacol. 308 (1996) 261 - 269.

[66] C.R. Gerfen, C.J. Wilson, The Basal Ganglia, in: L.W. Swanson, A. Björklund, T. Hökfelt (Eds.), Integrated systems of the CNS: Part III. Handbook of chemical neuroanatomy, vol. 12, Elsevier, Amsterdam, 1996, pp. $371-468$.

[67] K. Golembiowska, J. Konieczny, S. Wolfarth, K. Ossowska, Neuroprotective action of MPEP, a selective mGluR5 antagonist, in methamphetamine-induced dopaminergic neurotoxicity is associated with a decrease in dopamine outflow and inhibition of hyperthermia in rats, Neuropharmacology 45 (2003) 484 $-492$.

[68] W. Gong, D.B. Neill, M. Lynn, J.B. Justice Jr., Dopamine D1/D2 agonists injected into nucleus accumbens and ventral pallidum differentially affect locomotor activity depending on site, Neuroscience 93 (1999) $1349-1358$.

[69] J.T. Greenamyre, A.B. Young, Synaptic localization of striatal NMDA, quisqualate and kainate receptors, Neurosci. Lett. 101 (1989) 133 - 137.

[70] R.G. Greenslade, S.N. Mitchell, Selective action of (--)-2-oxa-4-aminobicyclo[3.1.0] hexane-4,6dicarboxylate (LY379268), a group II metabotropic glutamate receptor agonist, on basal and phencyclidine-induced dopamine release in the nucleus accumbens shell, Neuropharmacology 47 (2004) $1-8$.

[71] M.H. Hamilton, J.S. De Belleroche, I.M. Gardiner, L.J. Herberg, Stimulatory effect of N-methyl aspartate on locomotor activity and transmitter release from rat nucleus accumbens, Pharmacol. Biochem. Behav. 25 (1986) 943 - 948.

[72] L.G. Harsing Jr., E.S. Vizi, Alpha 2-adrenoceptors are not involved in the regulation of striatal glutamate release: comparison to dopaminergic inhibition, J. Neurosci. Res. 28 (1991) 376 - 381.

[73] J. Harvey, M.G. Lacey, A postsynaptic interaction between dopamine D1 and NMDA receptors promotes presynaptic inhibition in the rat nucleus accumbens via adenosine release, J. Neurosci. 17 (1997) $5271-5280$.

[74] W. Hauber, M. Munkle, Motor depressant effects mediated by dopamine D2 and adenosine A2A receptors in the nucleus accumbens and the caudate- putamen, Eur. J. Pharmacol. 323 (1997) 127 - 131.

[75] T. Honore, S.N. Davies, J. Drejer, E.J. Fletcher, P. Jacobsen, D. Lodge, F.E. Nielsen, Quinoxalinediones: potent competitive non-NMDA glutamate receptor antagonists, Science 241 (1988) $701-703$. 
[76] G. Hu, P. Duffy, C. Swanson, M.B. Ghasemzadeh, P.W. Kalivas, The regulation of dopamine transmission by metabotropic glutamate receptors, J. Pharmacol. Exp. Ther. 289 (1999) 412 - 416.

[77] Q. Huang, D. Zhou, K. Chase, J.F. Gusella, N. Aronin, M. DiFiglia, Immuno-histochemical localization of the D1 dopamine receptor in rat brain reveals its axonal transport, pre- and postsynaptic localization, and prevalence in the basal ganglia, limbic system, and thalamic reticular nucleus, Proc. Natl. Acad. Sci. U. S. A. 89 (1992) $11988-11992$.

[78] S. Ikemoto, Ventral striatal anatomy of locomotor activity induced by cocaine, d-amphetamine, dopamine and D1/D2 agonists, Neuroscience 113 (2002) 939 - 955.

[79] A. Imperato, G. Di Chiara, Effects of locally applied D-1 and D-2 receptor agonists and antagonists studied with brain dialysis, Eur. J. Pharmacol. 156 (1988) 385 - 393.

[80] A. Imperato, G. Di Chiara, CY 208-243, a novel dopamine D-1 receptor agonist, fails to modify dopamine release in freely moving rats, Eur. J. Pharmacol. 160 (1989) 155 - 158.

[81] A. Imperato, T. Honore, L.H. Jensen, Dopamine release in the nucleus caudatus and in the nucleus accumbens is under glutamatergic control through non-NMDA receptors: a study in freely-moving rats, Brain Res. 530 (1990) 223 - 228.

[82] A. Imperato, M.G. Scrocco, S. Bacchi, L. Angelucci, NMDA receptors and in vivo dopamine release in the nucleus accumbens and caudatus, Eur. J. Pharmacol. 187 (1990) 555 - 556.

[83] E. Ince, B.J. Ciliax, A.I. Levey, Differential expression of D1 and D2 dopamine and m4 muscarinic acetylcholine receptor proteins in identified striatonigral neurons, Synapse 27 (1997) 357 - 366.

[84] M.M. Iravani, Z.L. Kruk, Real-time effects of N-methyl-d-aspartic acid on dopamine release in slices of rat caudate putamen: a study using fast cyclic voltammetry, J. Neurochem. 66 (1996) 1076 - 1085.

[85] K. Jhamandas, M. Marien, Glutamate-evoked release of endogenous brain dopamine: inhibition by an excitatory amino acid antagonist and an enkephalin analogue, Br. J. Pharmacol. 90 (1987) 641 - 650.

[86] S. Jin, AMPA- and kainate-receptors differentially mediate excitatory amino acid-induced dopamine and acetylcholine release from rat striatal slices, Neuropharmacology 36 (1997) 1503 - 1510.

[87] S. Jin, B.B. Fredholm, Role of NMDA, AMPA and kainate receptors in mediating glutamate- and 4-APinduced dopamine and acetylcholine release from rat striatal slices, Neuropharmacology 33 (1994) 1039 $-1048$.

[88] D. Joel, I. Weiner, The connections of the dopaminergic system with the striatum in rats and primates: an analysis with respect to the functional and compartmental organization of the striatum, Neuroscience $96(2000) 451-474$.

[89] K.M. Johnson, Y.J. Jeng, Pharmacological evidence for N-methyl-D-aspartate receptors on nigrostriatal dopaminergic nerve terminals, Can. J. Physiol. Pharmacol. 69 (1991) 1416 - 1421.

[90] E.S. Jokel, E.R. Garduno, M.A. Ariano, M.S. Levine, Metabotropic glutamate receptors mGluR1alpha and mGluR2/3 display dynamic expression patterns in developing rat striatum, Dev. Neurosci. 23 (2001) 1 - 6.

[91] S.M. Jones, L.D. Snell, K.M. Johnson, Inhibition by phencyclidine of excitatory amino acid-stimulated release of neurotransmitter in the nucleus accumbens, Neuropharmacology 26 (1987) $173-179$.

[92] F.G. Kaddis, L.J. Wallace, N.J. Uretsky, AMPA/kainate antagonists in the nucleus accumbens inhibit locomotor stimulatory response to cocaine and dopamine agonists, Pharmacol. Biochem. Behav. 46 (1993) $703-708$.

[93] Y. Kawaguchi, Neostriatal cell subtypes and their functional roles, Neurosci. Res. 27 (1997) 1 - 8. 
[94] K.A. Keefe, M.J. Zigmond, E.D. Abercrombie, Extracellular dopamine in striatum: influence of nerve impulse activity in medial forebrain bundle and local glutamatergic input, Neuroscience 47 (1992) 325 332.

[95] K.A. Keefe, M.J. Zigmond, E.D. Abercrombie, In vivo regulation of extracellular dopamine in the neostriatum: influence of impulse activity and local excitatory amino acids, J. Neural Transm.: Gen. Sect. 91 (1993) $223-240$.

[96] A.E. Kelley, Neural integrative activities of nucleus accumbens subregions in relation to learning and motivation, Psychobioliogy 27 (1999) 198 - 213.

[97] A.E. Kelley, L.C. Throne, NMDA receptors mediate the behavioral effects of amphetamine infused into the nucleus accumbens, Brain Res. Bull. 29 (1992) 247 - 254.

[98] J.A. Kerner, D.G. Standaert, J.B. Penney Jr., A.B. Young, G.B. Landwehrmeyer, Expression of group one metabotropic glutamate receptor subunit mRNAs in neurochemically identified neurons in the rat neostriatum, neocortex, and hippocampus, Brain Res. Mol. Brain Res. 48 (1997) 259 - 269.

[99] A.S. Keys, G.P. Mark, D1 and D2 dopamine receptor mediation of amphetamine-induced acetylcholine release in nucleus accumbens, Neuroscience 82 (1998) 521 - 531.

[100] Z.U. Khan, A. Gutierrez, R. Martin, A. Penafiel, A. Rivera, A. de la Calle, Dopamine D5 receptors of rat and human brain, Neuroscience 100 (2000) 689 - 699.

[101] J.H. Kim, P. Vezina, Activation of metabotropic glutamate receptors in the rat nucleus accumbens increases locomotor activity in a dopamine-dependent manner, J. Pharmacol. Exp. Ther. 283 (1997) 962 968.

[102] J.H. Kim, J.A. Beeler, P. Vezina, Group II, but not group I, metabotropic glutamate receptors in the rat nucleus accumbens contribute to amphetamine-induced locomotion, Neuropharmacology 39 (2000) 1692 $-1699$.

[103] J. Knauber, U. Kischka, M. Roth, W.J. Schmidt, M. Hennerici, K. Fassbender, Modulation of striatal acetylcholine concentrations by NMDA and the competitive NMDA receptor-antagonist AP-5: an in vivo microdialysis study, J. Neural Transm. 106 (1999) 35 - 45.

[104] T.E. Koeltzow, M. Xu, D.C. Cooper, X.T. Hu, S. Tonegawa, M.E. Wolf, F.J. White, Alterations in dopamine release but not dopamine autoreceptor function in dopamine D3 receptor mutant mice, J. Neurosci. 18 (1998) 2231 - 2238.

[105] C.M. Kosinski, S. Risso-Bradley, P.J. Conn, A.I. Levey, G.B. Landwehrmeyer, J.B. Penney Jr., A.B. Young, D.G. Standaert, Localization of metabotropic glutamate receptor $7 \mathrm{mRNA}$ and mGluR7a protein in the rat basal ganglia, J. Comp. Neurol. 415 (1999) 266 - 284.

[106] S.A. Kotecha, J.N. Oak, M.F. Jackson, Y. Perez, B.A. Orser, H.H. Van Tol, J.F. MacDonald, A D2 class dopamine receptor transactivates a receptor tyrosine kinase to inhibit NMDA receptor transmission, Neuron 35 (2002) 1111 - 1122.

[107] M.O. Krebs, M.L. Kemel, C. Gauchy, M. Desban, J. Glowinski, Glycine potentiates the NMDA-induced release of dopamine through a strychnine-insensitive site in the rat striatum, Eur. J. Pharmacol. 166 (1989) $567-570$.

[108] M.O. Krebs, J.M. Desce, M.L. Kemel, C. Gauchy, G. Godeheu, A. Cheramy, J. Glowinski, Glutamatergic control of dopamine release in the rat striatum: evidence for presynaptic $\mathrm{N}$-methyl-d-aspartate receptors on dopaminergic nerve terminals, J. Neurochem. 56 (1991) 81 - 85. 
[109] M.O. Krebs, F. Trovero, M. Desban, C. Gauchy, J. Glowinski, M.L. Kemel, Distinct presynaptic regulation of dopamine release through NMDA receptors in striosome- and matrix-enriched areas of the rat striatum, J. Neurosci. 11 (1991) 1256 - 1262.

[110] M.O. Krebs, M.L. Kemel, C. Gauchy, M. Desban, J. Glowinski, Local GABAergic regulation of the Nmethyl-d-aspartate-evoked release of dopamine is more prominent in striosomes than in matrix of the rat striatum, Neuroscience 57 (1993) 249 - 260.

[111] U.O. Kronthaler, W.J. Schmidt, Activation of striatal group II metabotropic glutamate receptors has a differential effect on dopamine-D1 and -D2 receptor antagonist-induced hypokinesia in the rat, NaunynSchmiedeberg's Arch. Pharmacol. 361 (2000) 289 - 297.

[112] B. Landwehrmeyer, G. Mengod, J.M. Palacios, Differential visualization of dopamine D2 and D3 receptor sites in rat brain. A comparative study using in situ hybridization histochemistry and ligand binding autoradiography, Eur. J. Neurosci. 5 (1993) 145 - 153.

[113] B. Landwehrmeyer, G. Mengod, J.M. Palacios, Dopamine D3 receptor mRNA and binding sites in human brain, Brain Res. Mol. Brain Res. 18 (1993) 187 - 192.

[114] C. Le Moine, B. Bloch, D1 and D2 dopamine receptor gene expression in the rat striatum: sensitive cRNA probes demonstrate prominent segregation of D1 and D2 mRNAs in distinct neuronal populations of the dorsal and ventral striatum, J. Comp. Neurol. 355 (1995) 418 - 426.

[115] C. Le Moine, B. Bloch, Expression of the D3 dopamine receptor in peptidergic neurons of the nucleus accumbens: comparison with the D1 and D2 dopamine receptors, Neuroscience 73 (1996) 131 - 143.

[116] C. Le Moine, F. Tison, B. Bloch, D2 dopamine receptor gene expression by cholinergic neurons in the rat striatum, Neurosci. Lett. 117 (1990) $248-252$.

[117] D. Levesque, M.P. Martres, J. Diaz, N. Griffon, C.H. Lammers, P. Sokoloff, J.C. Schwartz, A paradoxical regulation of the dopamine D3 receptor expression suggets the involvement of an anterograde factor from dopamine neurons, Proc. Natl. Acad. Sci. U. S. A. 92 (1995) 1719 - 1723.

[118] V. Leviel, A. Gobert, B. Guibert, The glutamate-mediated release of dopamine in the rat striatum: further characterization of the dual excitatory- inhibitory function, Neuroscience 39 (1990) $305-312$.

[119] M. L'hirondel, A. Cheramy, G. Godeheu, F. Artaud, A. Saiardi, E. Borreli, J. Glowinski, Lack of autoreceptor-mediated inhibitory control of dopamine release in striatal synaptosomes of D2 receptordeficient mice, Brain Res. 792 (1998) 253 - 262.

[120] J. Liu, B. Moghaddam, Regulation of glutamate efflux by excitatory amino acid receptors: evidence for tonic inhibitory and phasic excitatory regulation, J. Pharmacol. Exp. Ther. 274 (1995) 1209 - 1215.

[121] G. Lombardi, M. Alesiani, P. Leonardi, G. Cherici, R. Pellicciari, F. Moroni, Pharmacological characterization of the metabotropic glutamate receptor inhibiting $\mathrm{D}-[3 \mathrm{H}]$-aspartate output in rat striatum, Br. J. Pharmacol. 110 (1993) 1407 - 1412.

[122] G. Lombardi, D.E. Pellegrini-Giampietro, P. Leonard, G. Cherici, R. Pellicciari, F. Moroni, The depolarization-induced outflow of $\mathrm{D}-[3 \mathrm{H}]$ aspartate from rat brain slices is modulated by metabotropic glutamate receptors, Neurochem. Int. 24 (1994) 525 - 532.

[123] G. Lombardi, P. Leonardi, F. Moroni, Metabotropic glutamate receptors, transmitter output and fatty acids: studies in rat brain slices, Br. J. Pharmacol. 117 (1996) 189 - 195.

[124] X.Y. Lu, M.B. Ghasemzadeh, P.W. Kalivas, Expression of D1 receptor, D2 receptor, substance P and enkephalin messenger RNAs in the neurons projecting from the nucleus accumbens, Neuroscience 82 (1998) $767-780$. 
[125] A.J. MacLennan, N. Lee, S.R. Vincent, D.W. Walker, D2 dopamine receptor mRNA distribution in cholinergic and somatostatinergic cells of the rat caudate- putamen and nucleus accumbens, Neurosci. Lett. 180 (1994) $214-218$.

[126] S. Maione, C.S. Biggs, F. Rossi, L.J. Fowler, P.S. Whitton, alpha-Amino-3-hydroxy-5-methyl-4isoxazolepropionate receptors modulate dopamine release in rat hippocampus and striatum, Neurosci. Lett. 193 (1995) $181-184$.

[127] L. Mao, J.Q. Wang, Protection against acute amphetamine-induced behavior by microinjection of a group II metabotropic glutamate receptor agonist into the dorsal striatum of rats, Neurosci. Lett. 270 (1999) $103-106$.

[128] L. Mao, J.Q. Wang, Motor stimulation following bilateral injection of the group-I metabotropic glutamate receptor agonist into the dorsal striatum of rats: evidence against dependence on ionotropic glutamate receptors, Psychopharmacology (Berlin) 148 (2000) 367 - 373.

[129] L. Mao, J.Q. Wang, Distinct inhibition of acute cocaine-stimulated motor activity following microinjection of a group III metabotropic glutamate receptor agonist into the dorsal striatum of rats, Pharmacol. Biochem. Behav. 67 (2000) 93 - 101.

[130] L. Mao, Y.S. Lau, J.Q. Wang, Activation of group III metabotropic glutamate receptors inhibits basal and amphetamine-stimulated dopamine release in rat dorsal striatum: an in vivo microdialysis study, Eur. J. Pharmacol. 404 (2000) 289 - 297.

[131] M. Marien, J. Brien, K. Jhamandas, Regional release of [3H] dopamine from rat brain in vitro: effects of opioids on release induced by potassium, nicotine, and L-glutamic acid, Can. J. Physiol. Pharmacol. 61 (1983) $43-60$.

[132] M. Marti, F. Mela, C. Bianchi, L. Beani, M. Morari, Striatal dopamine-NMDA receptor interactions in the modulation of glutamate release in the substantia nigra pars reticulata in vivo: opposite role for D1 and D2 receptors, J. Neurochem. 83 (2002) 635 - 644.

[133] L.J. Martin, C.D. Blackstone, R.L. Huganir, D.L. Price, Cellular localization of a metabotropic glutamate receptor in rat brain, Neuron 9 (1992) 259 - 270.

[134] D. Martinez-Fong, M.G. Rosales, J.L. Gongora-Alfaro, S. Hernandez, J. Aceves, NMDA receptor mediates dopamine release in the striatum of unanesthetized rats as measured by brain microdialysis, Brain Res. 595 (1992) 309 - 315.

[135] G. Maura, A. Giardi, M. Raiteri, Release-regulating D-2 dopamine receptors are located on striatal glutamatergic nerve terminals, J. Pharmacol. Exp. Ther. 247 (1988) 680 - 684.

[136] R.J. McPherson, J.F. Marshall, Intrastriatal AP5 differentially affects behaviors induced by local infusions of D1 vs. D2 dopamine agonists, Brain Res. 739 (1996) 19 - 25.

[137] M.E. Meyer, Effects of intraaccumbens dopamine agonist SK\&F38393 and antagonist SCH23390 on locomotor activities in rats, Pharmacol. Biochem. Behav. 45 (1993) 843 - 847.

[138] M.E. Meyer, C. Van Hartesveldt, T.J. Potter, Locomotor activity following intra-accumbens microinjections of dopamine D1 agonist SK\&F 38393 in rats, Synapse 13 (1993) 310 - 314.

[139] C. Missale, S.R. Nash, S.W. Robinson, M. Jaber, M.G. Caron, Dopamine receptors: from structure to function, Physiol. Rev. 78 (1998) 189 - 225.

[140] P.R. Mitchell, N.S. Doggett, Modulation of striatal [3H]-glutamic acid release by dopaminergic drugs, Life Sci. 26 (1980) 2073 - 2081. 
[141] G.J. Mogenson, M. Wu, Effects of administration of dopamine D2 agonist quinpirole on exploratory locomotion, Brain Res. 551 (1991) 216 - 220.

[142] B. Moghaddam, M.L. Bolinao, Glutamatergic antagonists attenuate ability of dopamine uptake blockers to increase extracellular levels of dopamine: implications for tonic influence of glutamate on dopamine release, Synapse 18 (1994) 337 - 342.

[143] M. Morari, W.T. O'Connor, U. Ungerstdt, C. Bianchi, K. Fuxe, Functional neuroanatomy of the nigrostriatal and striatonigral pathways as studied with dual probe microdialysis in the awake rat II. Evidence for striatal $\mathrm{N}$-methyl-d-aspartate receptor regulation of striatonigral GABAergic transmission and motor function, Neuroscience 72 (1996) 89 - 97.

[144] M. Morari, M. Marti, S. Sbrenna, K. Fuxe, C. Bianchi, L. Beani, Reciprocal dopamine- glutamate modulation of release in the basal ganglia, Neurochem. Int. 33 (1998) $383-397$.

[145] P.J. Morgane, J.R. Galler, D.J. Mokler, A reviex of systems and networks of the limbic forebrain/limbic midbrain, Prog. Neurobiol. 75 (2005) 143 - 160.

[146] A. Mori, T. Takahashi, Y. Miyashita, H. Kasai, Two distinct glutamatergic synaptic inputs to striatal medium spiny neurones of neonatal rats and paired-pulse depression, J. Physiol. 476 (1994) 217 - 228.

[147] M. Nankai, M. Klarica, D. Fage, C. Carter, Evidence for native NMDA receptor subtype pharmacology as revealed by differential effects on the NMDA-evoked release of striatal neuromodulators: eliprodil, ifenprodil and other native NMDA receptor subtype selective compounds, Neurochem. Int. 29 (1996) 529 -542 .

[148] M. Nankai, M. Klarica, D. Fage, C. Carter, The pharmacology of native N-methyl-d-aspartate receptor subtypes: different receptors control the release of different striatal and spinal transmitters, Prog. NeuroPsychopharmacol. Biol. Psychiatry 22 (1998) 35 - 64.

[149] M. Ochi, H. Inoue, S. Koizumi, S. Shibata, S. Watanabe, Long-term enhancement of dopamine release by high frequency tetanic stimulation via a $\mathrm{N}$-methyl-d-aspartate-receptor-mediated pathway in rat striatum, Neuroscience 66 (1995) 29 - 36.

[150] H. Ohishi, R. Shigemoto, S. Nakanishi, N. Mizuno, Distribution of the mRNA for a metabotropic glutamate receptor (mGluR3) in the rat brain: an in situ hybridization study, J. Comp. Neurol. 335 (1993) $252-266$.

[151] T. Ohmori, T. Koyama, F. Nakamura, P. Wang, I. Yamashita, Effect of phencyclidine on spontaneous and N-methyl-d-aspartate (NMDA)-induced efflux of dopamine from superfused slices of rat striatum, Neuropharmacology 31 (1992) 461 - 467.

[152] M. Ohno, S. Watanabe, Persistent increase in dopamine release following activation of metabotropic glutamate receptors in the rat nucleus accumbens, Neurosci. Lett. 200 (1995) 113 - 116.

[153] K. Ossowska, M. Karcz, J. Wardas, S. Wolfarth, Striatal and nucleus accumbens D1/D2 dopamine receptors in neuroleptic catalepsy, Eur. J. Pharmacol. 182 (1990) 327 - 334.

[154] A. Ouagazzal, M. Amalric, Competitive NMDA receptor antagonists do not produce locomotor hyperactivity by a dopamine-dependent mechanism, Eur. J. Pharmacol. 294 (1995) 137 - 146.

[155] J. Patel, S.J. Trout, P. Palij, R. Whelpton, Z.L. Kruk, Biphasic inhibition of stimulated endogenous dopamine release by 7-OH-DPAT in slices of rat nucleus accumbens, Br. J. Pharmacol. 115 (1995) 421 426. 
[156] D.R. Patel, A.M.J. Young, M.J. Croucher, Presynaptic a-amino-3-hydroxy-5-methyl-4-isoxazole propionate receptor-mediated stimulation of glutamate and GABA release in the rat striatum in vivo: a dual-label microdialysis study, Neuroscience 102 (2001) 101 - 111.

[157] J. Peris, L.P. Dwoskin, N.R. Zahniser, Biphasic modulation of evoked [3H]D-aspartate release by D-2 dopamine receptors in rat striatal slices, Synapse 2 (1988) 450 - 456.

[158] R.S. Petralia, Y.X. Wang, A.S. Niedzielski, R.J. Wenthold, The metabotropic glutamate receptors, mGluR2 and mGluR3, show unique postsynaptic, presynaptic and glial localizations, Neuroscience 71 (1996) $949-976$.

[159] V.I. Petrov, V.S. Sergeyev, N.V. Onishchenko, The effect of N-acetyl-l-aspartic acid dilithium salt on dopamine release and synthesis in the rat striatum in vivo, Eur. J. Pharmacol. 416 (2001) 69 - 73.

[160] J.P. Pin, C. DeColle, A.S. Bessis, F. Acher, New perspectives for the development of selective metabotropic glutamate receptor ligands, Eur. J. Pharmacol. 375 (1999) 277 - 294.

[161] A. Pintor, A. Pezzola, R. Reggio, D. Quarta, P. Popoli, The mGlu5 receptor agonist CHPG stimulates striatal glutamate release: possible involvement of A2A receptors, NeuroReport 11 (2000) 3611 - 3614 .

[162] A. Pisani, P. Bonsi, D. Centonze, P. Calabresi, G. Bernardi, Activation of D2-like dopamine receptors reduces synaptic inputs to striatal cholinergic interneurons, J. Neurosci. 20 (2000) RC69.

[163] A. Pisani, P. Bonsi, D. Centonze, G. Bernardi, P. Calabresi, Functional coexpression of excitatory mGluR1 and mGluR5 on striatal cholinergic interneurons, Neuropharmacology 40 (2001) 460 - 463.

[164] A. Pisani, P. Bonsi, M.V. Catania, R. Giuffrida, M. Morari, M. Marti, D. Centonze, G. Bernardi, A.E. Kingston, P. Calabresi, Metabotropic glutamate 2 receptors modulate synaptic inputs and calcium signals in striatal cholinergic interneurons, J. Neurosci. 22 (2002) 6176 - 6185.

[165] A. Plaznik, R. Stefanski, W. Kostowski, Interaction between accumbens D1 and D2 receptors regulating rat locomotor activity, Psychopharmacology (Berlin) 99 (1989) 558 - 562.

[166] A. Porras, F. Mora, Dopamine- glutamate- GABA interactions and ageing: studies in the striatum of the conscious rat, Eur. J. Neurosci. 7 (1995) $2183-2188$.

[167] T.A. Pugsley, M.D. Davis, H.C. Akunne, R.G. MacKenzie, Y.H. Shih, G. Damsma, H. Wikstrom, S.Z. Whetzel, L.M. Georgic, L.W. Cooke, Neurochemical and functional characterization of the preferentially selective dopamine D3 agonist PD 128907, J. Pharmacol. Exp. Ther. 275 (1995) 1355 - 1366.

[168] S. Rahman, W.J. McBride, Feedback control of mesolimbic somatodendritic dopamine release in rat brain, J. Neurochem. 74 (2000) $684-692$.

[169] A. Rakovska, D. Javitt, P. Raichev, R. Ang, A. Balla, J. Aspromonte, S. Vizi, Physiological release of striatal acetylcholine (in vivo): effect of somatostatin on dopaminergic- cholinergic interaction, Brain Res. Bull. 61 (2003) $529-536$.

[170] R.W. Ransom, N.L. Deschenes, Glycine modulation of NMDA-evoked release of [3H]acetylcholine and [3H]dopamine from rat striatal slices, Neurosci. Lett. 96 (1989) $323-328$.

[171] S.M. Rawls, J.F. McGinty, L-trans-pyrrolidine-2,4-dicarboxylic acidevoked striatal glutamate levels are attenuated by calcium reduction, tetrodotoxin, and glutamate receptor blockade, J. Neurochem. 68 (1997) 1553 - 1563.

[172] M.G. Richard, J.P. Bennett Jr., NMDA receptor blockade increases in vivo striatal dopamine synthesis and release in rats and mice with incomplete, dopamine-depleting, nigrostriatal lesions, J. Neurochem. 64 (1995) $2080-2086$. 
[173] A. Rivera, B. Cuellar, F.J. Giron, D.K. Grandy, A. de la Calle, R. Moratalla, Dopamine D4 receptors are heterogeneously distributed in the striosomes/matrix compartments of the striatum, J. Neurochem. 80 (2002) $219-229$.

[174] P.J. Roberts, S.D. Anderson, Stimulatory effect of L-glutamate and related amino acids on [3H]dopamine release from rat striatum: an in vitro model for glutamate actions, J. Neurochem. 32 (1979) $1539-1545$.

[175] P.J. Roberts, N.A. Sharif, Effects of L-glutamate and related amino acids upon the release of [3H]dopamine from rat striatal slices, Brain Res. 157 (1978) 391 - 395.

[176] G.S. Robertson, M. Jian, D1 and D2 dopamine receptors differentially increase Fos-like immunoreactivity in accumbal projections to the ventral pallidum and midbrain, Neuroscience 64 (1995) $1019-1034$.

[177] G.F. Rowlands, P.J. Roberts, Activation of dopamine receptors inhibits calcium-dependent glutamate release from cortico-striatal terminals in vitro, Eur. J. Pharmacol. 62 (1980) $241-242$.

[178] M.I. Rudolph, L. Arqueros, G. Bustos, L-glutamic acid, a neuromodulator of dopaminergic transmission in the rat corpus striatum, Neurochem. Int. 5 (1983) $479-486$.

[179] A.I. Sacaan, J.A. Monn, D.D. Schoepp, Intrastriatal injection of a selective metabotropic excitatory amino acid receptor agonist induces contralateral turning in the rat, J. Pharmacol. Exp. Ther. 259 (1991) $1366-1370$.

[180] A.I. Sacaan, F.P. Bymaster, D.D. Schoepp, Metabotropic glutamate receptor activation produces extrapyramidal motor system activation that is mediated by striatal dopamine, J. Neurochem. 59 (1992) $245-251$.

[181] G. Sadri-Vakili, D.W. Johnson, G.C. Janis, T.T. Gibbs, R.C. Pierce, D.H. Farb, Inhibition of NMDAinduced striatal dopamine release and behavioral activation by the neuroactive steroid 3alpha-hydroxy5beta-pregnan-20-one hemisuccinate, J. Neurochem. 86 (2003) 92 - 101.

[182] K. Sakai, K. Akiyama, K. Kashihara, K. Tsuchida, H. Ujike, S. Kuroda, T. Shohmori, AMPA receptors modulate dopamine release in the striatum, as measured by brain microdialysis, Neurochem. Int. 30 (1997) $329-336$.

[183] W.J. Schmidt, D. Bury, Behavioural effects of N-methyl-d-aspartate in the anterodorsal striatum of the rat, Life Sci. 43 (1988) 545 - 549.

[184] A.N. Schoffelmeer, L.J. Vanderschuren, T.J. De Vries, F. Hogenboom, G. Wardeh, A.H. Mulder, Synergistically interacting dopamine D1 and NMDA receptors mediate nonvesicular transporterdependent GABA release from rat striatal medium spiny neurons, J. Neurosci. 20 (2000) 3496 - 3503.

[185] L. Scott, M.S. Kruse, H. Forssberg, H. Brismar, P. Greengard, A. Aperia, Selective up-regulation of dopamine D1 receptors in dendritic spines by NMDA receptor activation, Proc. Natl. Acad. Sci. U. S. A. 99 (2002) $1661-1664$.

[186] P. Seeman, H.H. Van Tol, Dopamine receptor pharmacology, Trends Pharmacol. Sci. 15 (1994) 264 270.

[187] S.R. Sesack, C. Aoki, V.M. Pickel, Ultrastructural localization of D2 receptor-like immunoreactivity in midbrain dopamine neurons and their striatal targets, J. Neurosci. 14 (1994) 88 - 106.

[188] R. Shigemoto, S. Nakanishi, N. Mizuno, Distribution of the mRNA for a metabotropic glutamate receptor (mGluR1) in the central nervous system: an in situ hybridization study in adult and developing rat, J. Comp. Neurol. 322 (1992) 121 - 135. 
[189] R. Shigemoto, S. Nomura, H. Ohishi, H. Sugihara, S. Nakanihi, N. Mizuno, Immunohistochemical localization of a metabotropic glutamate receptor, mGluR5, in the rat brain, Neurosci Lett. 163 (1993) 53 57.

[190] P.E. Shreve, N.J. Uretsky, Role of quisqualic acid receptors in the hypermotility response produced by the injection of AMPA into the nucleus accumbens, Pharmacol. Biochem. Behav. 30 (1988) $379-384$.

[191] I. Smolders, S. Sarre, C. Vanhaesendonck, G. Ebinger, Y. Michotte, Extracellular striatal dopamine and glutamate after decortication and kainate receptor stimulation, as measured by microdialysis, J. Neurochem. 66 (1996) 2373 - 2380.

[192] L.D. Snell, K.M. Johnson, Characterization of the inhibition of excitatory amino acid-induced neurotransmitter release in the rat striatum by phencyclidine-like drugs, J. Pharmacol. Exp. Ther. 238 (1986) 938 - 946.

[193] P. Sokoloff, B. Giros, M.P. Martres, M.L. Bouthenet, J.C. Schwartz, Molecular cloning and characterization of a novel dopamine receptor (D3) as a target for neuroleptics, Nature 347 (1990) 146 151.

[194] J.C. Stoof, T. De Boer, P. Sminia, A.H. Mulder, Stimulation of D2-dopamine receptors in rat neostriatum inhibits the release of acetylcholine and dopamine but does not affect the release of gammaaminobutyric acid, glutamate or serotonin, Eur. J. Pharmacol. 84 (1982) 211 - 214.

[195] J.C. Stoof, P.F. Verheijden, J.E. Leysse, Stimulation of D2-receptors in rat nucleus accumbens slices inhibits dopamine and acetylcholine release but not cyclic AMP formation, Brain Res. 423 (1987) 364 368.

[196] C.J. Swanson, P.W. Kalivas, Regulation of locomotor activity by metabotropic glutamate receptors in the nucleus accumbens and ventral tegmental area, J. Pharmacol. Exp. Ther. 292 (2000) $406-414$.

[197] C.J. Swanson, S. Heath, T.R. Stratford, A.E. Kelley, Differential behavioral responses to dopaminergic stimulation of nucleus accumbens subregions in the rat, Pharmacol. Biochem. Behav. 58 (1997) 933 - 945.

[198] C.J. Swanson, D.A. Baker, D. Carson, P.F. Worley, P.W. Kalivas, Repeated cocaine administration attenuates group I metabotropic glutamate receptor-mediated glutamate release and behavioral activation: a potential role for Homer, J. Neurosci. 21 (2001) 9043 - 9052.

[199] M.T. Taber, G.B. Baker, H.C. Fibiger, Glutamate receptor agonists decrease extra-cellular dopamine in the rat nucleus accumbens in vivo, Synapse 24 (1996) 165 - 172.

[200] P. Taepavarapruk, S.B. Floresco, A.G. Phillips, Hyperlocomotion and increased dopamine efflux in the rat nucleus accumbens evoked by electrical stimulation of the ventral subiculum: role of ionotropic glutamate and dopamine D1 receptors, Psychopharmacology (Berlin) 151 (2000) 242 - 251.

[201] Y. Takumi, A. Matsubara, E. Rinvik, O.P. Ottersen, The arrangement of glutamate receptors in excitatory synapses, Ann. N. Y. Acad. Sci. 868 (1999) $474-482$.

[202] S.J. Tallaksen-Greene, R.L. Albin, Localization of AMPA-selective excitatory amino acid receptor subunits in identified populations of striatal neurons, Neuroscience 61 (1994) 509 - 519.

[203] S.J. Tallaksen-Greene, K.W. Kaatz, C. Romano, R.L. Albin, Localization of mGluR1a-like immunoreactivity and mGluR5-like immunoreactivity in identified populations of striatal neurons, Brain Res. 780 (1998) 210 - 217.

[204] Y. Tamaru, S. Nomura, N. Mizuno, R. Shigemoto, Distribution of metabotropic glutamate receptor mGluR3 in the mouse CNS: differential location relative to pre and postsynaptic sites, Neuroscience 106 (2001) $481-503$. 
[205] F.I. Tarazi, R.J. Baldessarini, Regional localization of dopamine and ionotropic glutamate receptor subtypes in striatolimbic brain regions, J. Neurosci. Res. 55 (1999) 401 - 410.

[206] F.I. Tarazi, A. Campbell, R.J. Baldessarini, Effects of hippocampal lesions on striatolimbic ionotropic glutamatergic receptors, Neurosci. Lett. 250 (1998) 13 - 16.

[207] F.I. Tarazi, A. Campbell, S.K. Yeghiayan, R.J. Baldessarini, Localization of ionotropic glutamate receptors in caudate- putamen and nucleus accumbens septi of rat brain: comparison of NMDA, AMPA, and kainate receptors, Synapse 30 (1998) 227 - 235.

[208] F.I. Tarazi, A. Campbell, S.K. Yeghiayan, R.J. Baldessarini, Localization of dopamine receptor subtypes in corpus striatum and nucleus accumbens septi of rat brain: comparison of D1-, D2-, and D4-like receptors, Neuroscience 83 (1998) 169 - 176.

[209] C.M. Testa, D.G. Standaert, A.B. Young, J.B. Penney Jr., Metabotropic glutamate receptor mRNA expression in the basal ganglia of the rat, J. Neurosci. 14 (1994) $3005-3018$.

[210] C.M. Testa, D.G. Standaert, G.B. Landwehrmeyer, J.B. Penney Jr., A.B. Young, Differential expression of mGluR5 metabotropic glutamate receptor mRNA by rat striatal neurons, J. Comp. Neurol. 354 (1995) 241 -252 .

[211] C.M. Testa, I.K. Friberg, S.W. Weiss, D.G. Standaert, Immunohistochemical localization of metabotropic glutamate receptors mGluR1a and mGluR2/3 in the rat basal ganglia, J. Comp. Neurol. 390 (1998) 5- 19.

[212] P.K. Thanos, K. Jhamandas, R.J. Beninger, N-methyl-d-aspartate unilaterally injected into the dorsal striatum of rats produces contralateral circling: antagonism 2-amino-7-phosphonoheptanoic acid and cisfluxenthixol, Brain Res. 589 (1992) 55 - 61.

[213] W. Timmerman, J.B. De Vries, B.H. Westerink, Effects of D-2 agonists on the release of dopamine: localization of the mechanism of action, Naunyn-Schmiedeberg's Arch. Pharmacol. 342 (1990) 650 - 654.

[214] R. Van den Boss, A.R. Cools, S.O. Ogren, Differential effects of the selective D2-antagonist raclopride in the nucleus accumbens of the rat on spontaneous and d-amphetamine-induced activity, Psychopharmacology (Berlin) 95 (1988) 447 - 451.

[215] C. Van Hartesveldt, G.A. Cottrell, T. Potter, M.E. Meyer, Effects of intracerebral quinpirole on locomotion in rats, Eur. J. Pharmacol. 214 (1992) 27 - 32.

[216] A. Verma, B. Moghaddam, Regulation of striatal dopamine release by metabotropic glutamate receptors, Synapse 28 (1998) 220 - 226.

[217] S.R. Wachtel, X.T. Hu, M.P. Galloway, F.J. White, D1 dopamine receptor stimulation enables the postsynaptic, but not autoreceptor, effects of D2 dopamine agonists in nigrostriatal and mesoaccumbens dopamine systems, Synapse 4 (1989) 327 - 346.

[218] J.R. Walters, D.A. Bergstrom, J.H. Carlson, T.N. Chase, A.R. Braun, D1 dopamine receptor activation required for postsynaptic expression of D2 agonist effects, Science 236 (1987) 719 - 722.

[219] J.K. Wang, Presynaptic glutamate receptors modulate dopamine release from striatal synaptosomes, J. Neurochem. 57 (1991) $819-822$.

[220] J.Q. Wang, L. Mao, Sustained behavioral stimulation following selective activation of group I metabotropic glutamate receptors in rat striatum, Pharmacol. Biochem. Behav. 65 (2000) 439 - 447.

[221] L.L. Werling, H.M. Jacocks III, P.N. McMahon, Regulation of [3H]dopamine release from guinea pig striatum by NMDA receptor/channel activators and inhibitors, J. Pharmacol. Exp. Ther. 255 (1990) 40 45 . 
[222] B.H. Westerink, P. De Boer, W. Timmerman, J.B. De Vries, In vivo evidence for the existence of autoreceptors on dopaminergic, serotonergic, and cholinergic neurons in the brain, Ann. N. Y. Acad. Sci. 604 (1990) $492-504$.

[223] B.H. Westerink, M. Santiago, J.B. De Vries, The release of dopamine from nerve terminals and dendrites of nigrostriatal neurons induced by excitatory amino acids in the conscious rat, NaunynSchmiedeberg's Arch. Pharmacol. 345 (1992) 523 - 529.

[224] D. Wheeler, M.G. Boutelle, M. Fillenz, The role of N-methyl-d-aspartate receptors in the regulation of physiologically released dopamine, Neuroscience 65 (1995) 767 - 774.

[225] F.J. White, D-1 dopamine receptor stimulation enables the inhibition of nucleus accumbens neurons by a D-2 receptor agonist, Eur. J. Pharmacol. 135 (1987) $101-105$.

[226] P.S. Whitton, S. Maione, C.S. Biggs, L.J. Fowler, N-methyl-d-aspartate receptors modulate extracellular dopamine concentration and metabolism in rat hippocampus and striatum in vivo, Brain Res. 635 (1994) $312-316$.

[227] M. Wu, S.M. Brudzynski, G.J. Mogenson, Differential effects of quinpirole in the nucleus accumbens depending on the initial level of locomotor activity, Brain Res. Bull. 32 (1993) 395 - 398.

[228] M. Wu, S.M. Brudzynski, G.J. Mogenson, Functional interactions of dopamine and glutamate in the nucleus accumbens in the regulation of locomotion, Can. J. Physiol. Pharmacol. 71 (1993) 407 - 413.

[229] Y. Wu, S.M. Pearl, M.J. Zigmond, A.C. Michael, Inhibitory glutamatergic regulation of evoked dopamine release in striatum, Neuroscience 96 (2000) $65-72$.

[230] U. Wullner, D.G. Standaert, C.M. Testa, G.B. Landwehrmeyer, M.V. Catania, J.B. Penney Jr., A.B. Young, Glutamate receptor expression in rat striatum: effect of deafferentation, Brain Res. 647 (1994) 209 - 219.

[231] Z.X. Xi, D.A. Baker, H. Shen, D.S. Carson, P.W. Kalivas, Group II metabotropic glutamate receptors modulate extracellular glutamate in the nucleus accumbens, J. Pharmacol. Exp. Ther. 300 (2002) 162 171.

[232] Z.X. Xi, H. Shen, D.A. Baker, P.W. Kalivas, Inhibition of nonvesicular glutamate release by group III metabotropic glutamate receptors in the nucleus accumbens, J. Neurochem. 87 (2003) $1204-1212$.

[233] S. Yamada, H. Yokoo, S. Nishi, Differential effects of dopamine agonists on evoked dopamine release from slices of striatum and nucleus accumbens in rats, Brain Res. 648 (1994) $176-179$.

[234] B.K. Yamamoto, S. Davy, Dopaminergic modulation of glutamate release in striatum as measured by microdialysis, J. Neurochem. 58 (1992) 1736 - 1742.

[235] Y. Yamamoto, T. Kakigi, K. Maeda, Intra-striatal phencyclidine inhibits N-methyl-d-aspartic acidstimulated increase in glutamate levels of freely moving rats, Prog. Neuro-Psychopharmacol. Biol. Psychiatry 23 (1999) $161-174$.

[236] Z. Yan, D.J. Surmeier, D5 dopamine receptors enhance Zn2+- sensitive GABA(A) currents in striatal cholinergic interneurons through a PKA/PP1 cascade, Neuron 19 (1997) 1115 - 1126.

[237] Z. Yan, W.J. Song, J. Surmeier, D2 dopamine receptors reduce N-type Ca2+ currents in rat neostriatal cholinergic interneurons through a membrane-delimited, protein-kinase-C-insensitive pathway, J. Neurophysiol. 77 (1997) 1003 - 1015.

[238] K.K. Yung, J.P. Bolam, A.D. Smith, S.M. Hersch, B.J. Ciliax, A.I. Levey, Immunocytochemical localization of D1 and D2 dopamine receptors in the basal ganglia of the rat: light and electron microscopy, Neuroscience 65 (1995) 709 - 730. 
[239] K. Zavitsanou, A. Mitsacos, P. Giompres, E.D. Kouvelas, Changes in [3H]AMPA and [3H]kainate binding in rat caudate- putamen and nucleus accumbens after 6-hydroxydopamine lesions of the medial forebrain bundle: an autoradiographic study, Brain Res. 731 (1996) 132 - 140.

[240] H. Zhang, D. Sulzer, Glutamate spillover in the striatum depresses dopaminergic transmission by activating group I metabotropic glutamate receptors, J. Neurosci. 23 (2003) 10585 - 10592.

[241] P. Zheng, X.X. Zhang, B.S. Bunney, W.X. Shi, Opposite modulation of cortical N-methyl-d-aspartate receptor-mediated responses by low and high concentrations of dopamine, Neuroscience 91 (1999) 527 535. 